Amasya Ilahiyat Dergisi - Amasya Theology Journal

ISSN 2667-7326 | e-ISSN 2667-6710

Haziran / June 2020, 14: 293-326

\title{
Abdülğanî b. İsmâil en-Nablusî (ö. 1143/1731) ve Miftâhu'l-Ma'ıyye Adlı Eseri Çerçevesinde Nakşibendî Tarikatının On Bir Esâsı
}

\section{The Eleven Principles of Naqshibandiyya Tariqa in the Framework of Abdulgani b. Ismail an-Nablusi (d. 1143/1731) and Miftâhu'l- Ma'tyye}

\author{
Mevlüt ÖZÇELIKK \\ Dr. Öğr. Üyesi, Amasya Üniversitesi, İlahiyat Fakültesi, \\ Tasavvuf Anabilim Dalı \\ Assistant Professor, Amasya University, Faculty of Theology, \\ Department of Sufism \\ Amasya, Turkey \\ mozcelik42@gmail.com \\ orcid.org/0000-0003-1434-2135
}

\section{Makale Bilgisi / Article Information}

Makale Türü / Article Types: Araştırma Makalesi / Research Article Geliş Tarihi / Received: 18 Ağustus / August 2018 Kabul Tarihi / Accepted: 10 Ekim / October 2018 Yayın Tarihi / Published: 30 Haziran / June 2020 Yayin Sezonu / Pub. Date Season: Haziran / June Sayı / Issue: 14 Sayfa / Pages: 293-326

Atıf / Cite as: Özçelik, Mevlüt. “Abdülğanî b. İsmâil en-Nablusî (ö. 1143/1731) ve Miftâhu'l-Ma'ıyye Adlı Eseri Çerçevesinde Nakşibendî Tarikatının On Bir Esâsı [The Eleven Principles of Naqshibandiyya Tariqa in the Framework of Abdulgani b. Ismail an-Nablusi (d. 1143/1731) and Miftâhu'l-Ma'ıyye]". Amasya Illahiyat Dergisi-Amasya Theology Journal 14 (June 2020): 293-326. https://doi.org/10.18498/amailad.581697.

İntihal / Plagiarism: Bu makale, en az iki hakem tarafından incelendi ve intihal içermediği teyit edildi. / This article has been reviewed by at least two referees and scanned via a plagiarism software. 
294 | M. ÖZÇELIK / Abdülğanî b. İsmâil en-Nablusî (ö. 1143/1731) ve Miftâhu'l-Ma'ryye Adlı Eseri Çerçevesinde Nakşibendî Tarikatının On Bir Esâsı

Copyright $\odot$ Published by Amasya Üniversitesi, İlahiyat Fakültesi / Amasya University, Faculty of Theology, Amasya, 05100 Turkey. All rights reserved. https://dergipark.org.tr/amailad.

\section{The Eleven Principles of Naqshibandiyya Tariqa in the Framework} of Abdulgani b. Ismail an-Nablusi (d. 1143/1731) and Miftâhu'l-Ma'ıyye

\section{Abstract}

Nablusî (d. 1143/1731), who played an important role in shaping of spiritual life in Syria in the age of his life (17th-18th centuries), was a scholar in material and spiritual sciences authorized by Kadiriyya Tariqa and Naqshibandiyya Tariqa. The most striking works of Nablusî, who wrote about three hundred works, are those related to mysticism. One of these books is Miftâhu'l-ma'ryye fi düstûri'ttarîkati'n-Nakşibendiyye. This book is an explanation of the book Tâciyye written by Tajuddin b. Zakariyya (d. 1050/1640). This article aims to reveal the viewpoint of Nablusi on the eleven principles of Naqshbandiyya by taking the mentioned book into the center. Eleven principles determined by Abdulhalik-i Gucduvani (d. 612/1220) and Bahauddin Naqshiband (d. 791/1389) are called Kelimât-i Kudsiyya. The basic goal of these principles, expressed in Persian words, is to provide spiritual development of the disciples.

The first of these eleven principles (Yâd Kerd) always advises to remember the Almighty God. The second principle (Bâz Geşt), humbly advises to return to God. The third principle (Nigâh Dâşt), advises protecting the heart against any thought. The fourth principle advises to preserve the state of return to the heart with the heart and to remember Allâh forever. The fifth principle (Hûş DerDem), advises taking every breath consciously. The sixth principle (Sefer Der Vatan), advises to move away from the people and to return to God; The seventh principle (Nazar Ber-Kadem), advises that you take each step carefully. The eighth principle (Halvet Der Encümen), advises to be with God among the people; the ninth principle (Vukûf-i Zamânî), proposes to spend all time consciously. The tenth principle (Vukûf-i Adedî) advises to abide by the number of dhikr; eleventh principle (Vukûf-i Kalbî), advises to keep the heart under constant control.

\section{Summary}

Nablusi who was one of the masters of spiritual life in Syria between the 17th and 18th centuries, wrote his work Miftâhu'l-Maryye as a commentary on Tâciyye written by Tajuddin b. Zakariyya who one of the most important people of 
Naqshbandiyya. This study aims to reveal the perspective of Nablusi on the eleven principles of Naqshbandiyya. We can briefly summarize these eleven principles:

The first principle is Yâd Kard. This principle states that the disciple should always remember Almighty Allah by saying "lâ ilâha illallâh" every day, with his tongue and heart, as much as he is recommended to him. Making this dhikr continuously, leads to enlightening the heart. Enlighten the heart, leads to purify the heart from all existence except Almighty Allah.

The second principle is Bâz Gâsht. This principle, advises to avoid good or bad thoughts that come from spontaneous memory at the time of remembrance. According to Nablusi, the dhikr must be purified from creatures other than Allah until he becomes real dhikr.

The third principle is Nigâh Dâsht. This principle states that the heart must be protected from khawater when reading Kalima Tawhid. According to Nablusi khawater are thoughts of the kind of good and evil that comes to the heart. The prevention of these thoughts depends on the repetition of Kalima Tawhid over and over and not bringing any feelings or thoughts to mind.

The fourth principle is Yâd Dâsht. This principle, states that the disciple should always envisage himself in the presence of Almighty Allâh. According to nablusi, this concept shouldn't be in the form of trying to imagine Allâh, but rather in the form of envisioning that it is in front of Allâh.

The fifth principle is Hîşh Dar-Dam. This principle, advises the disciple to take every breath as if it were in front of Allah. According to Nablusi, a disciple who thinks that he is in front of Allâh should give his breath consciously. The breath coming out of mouth is more important than the breath, which entered the mouth. Because the person can't control the breath that goes into his mouth, but he can control the breath that goes out of his mouth. Therefore, the disciple must consciously give every breath out of his mouth.

The sixth principle is Safar Dar-Vatan. This principle, states that the disciple should move away from the people and turn to Allâh. According to Nablusi, servant's turning to Allâh takes place by moving away from his bad qualities such as greed and miserliness in his soul and by equipping with good qualities such as tolerance and generosity.

The seventh principle is Nazar Bar-Qadam. This principle, instructs the disciple to carefully take every step he takes, to protect his eyes from haram and unnecessary things, and to bend his head and walk by looking at his feet in order not to distract him. According to Nablusi, walking by looking at the feet 
296 | M. ÖZÇELIK / Abdülğanî b. İsmâil en-Nablusî (ö. 1143/1731) ve Miftâhu'l-Ma'tyye Adlı Eseri Çerçevesinde Nakşibendî Tarikatının On Bir Esâsı

carries the aim of not seeing the behavior of blind people and not interested in their behavior. Because looking at those who are spiritually awake leads to spiritual alertness, and looking at those unaware leads to unawareness.

The eighth principle is Khalwat Dar Anjuman. This principle, states that the disciple should be with his heart in the front of Almighty Allah, even though he is with his body among the people. According to Nablusi, being with body among people is done with proper actions, words that do not cause sin, and acts with them in all kinds of worship. Being front of Allâh with the heart, takes place by thinking about Allâh and turning away from other beings.

The ninth principle is Wuqûf-i Zamânî. This principle, means that the disciple, must consciously spend all her time and question herself all the time. The disciple should be grateful to Allâh for every time he does good work and repent for every time he does bad work.

The tenth principle is Wuqûf-i Adadî. This principle, states that it is necessary to follow a certain number in dhikr. According to Nablusi, the determination of a certain number in the dhikr is formed to exercise the nafs into a number and to gather fragmented thoughts around a single thought. Therefore, the disciple must adhere to the recommended dhikr number.

The eleventh principle is Wuqûf-i Qalbî. This principle, states that the heart must be in the face of Allâh without any other purpose than Allâh. This happens when the disciple sees the work of Allâh in everything he looks at.

Keywords: Mysticism, Naqshbandiyya, Eleven principles, Nablusî, Miftâhu'lma'1yye.

\section{Abdülğanî b. İsmâil en-Nablusî (ö. 1143/1731) ve Miftâhu'l-Ma'ıyye Adlı Eseri Çerçevesinde Nakşibendî Tarikatının On Bir Esâsı}

\section{Öz}

Yaşadığı çağda (XVII-XVIII. y.y.) Suriye'deki mânevî hayatın teşekkülünde önemli rol oynayan Nablusî (ö. 1143/1731), Kâdiriyye ve Nakşibendiyye tarikatlarından hırka giyen, zâhirî ve tasavvufî ilimlerde söz sâhibi olan bir âlimdir. Üç yüz kadar eser telif eden Nablusî́nin en dikkat çeken eserleri, tasavvufla ilgili olanlarıdır. Bu kitaplardan biri de Miftâhu'l-ma'tyye fì düstûri'ttarîkati'n-Nakşibendiyye adlı eserdir. Bu kitap, Tâcüddin b. Zekeriyyâ'nın (ö. 1050/1640) Tâciyye isimli eserinin şerhidir. Bu makale, adı geçen kitabı merkeze alarak Nakşibendiyye'nin on bir esâsı hakkında Nablusî'nin bakış açısını ortaya koymayı amaçlamaktadır. Abdülhâlik-ı Gücdüvânî (ö. 612/1220) ve Bahâüddîn Nakşibend (ö. 791/1389) tarafından ortaya konan on bir esâs, Kelimât-ı Kudsiye 
olarak adlandırılır. Farsça kelimelerle ifâde edilen bu esasların temel hedefi, müritlerin mânevi gelişimini sağlamaktır.

Birinci esâs (Yâd Kerd), sürekli olarak yüce Allâh'1 zikretmeyi, ikinci esâs (Bâz Geşt), tevâzuyla Allâh'a yönelmeyi, üçüncü esâs (Nigâh Dâşt), kalbi havâtıra karşı korumayı, dördüncü esâs (Yâd Daşt), kalben Allâh'a dönüş hâlini muhâfaza edip devamlı olarak Allâh'ı hatırda tutmayı, beşinci esâs (Hûş DerDem), her nefesi bilinçli bir şekilde alıp vermeyi, altıncı esâs (Sefer Der Vatan), halktan uzaklaşıp Allâh'a yönelmeyi, yedinci esâs, (Nazar Ber-Kadem) atılan her adımı dikkatli bir şekilde atmayı, sekizinci esâs (Halvet Der Encümen), halk içinde iken Allâh ile birlikte olmayı, dokuzuncu esâs (Vukûf-i Zamânî), her ânı bilinçli olarak geçirmeyi, onuncu esâs (Vukûf-i Adedî), zikir adedine riayet etmeyi, on birinci esâs (Vukûf-i Kalbî) ise kalbi sürekli kontrol altında tutmayı öğütler.

Anahtar Kelimeler: Tasavvuf, Nakşibendiyye, On bir esâs, Nablusî, Miftâhu'1ma'iyye.

\section{Giriş}

İslam telif tarihinde bazı eserler, kısa ve öz olarak yazılmıştır. İhtisas sahibi olmayan kimselerin bu veciz ifâdeleri anlaması mümkün değildir. Bu sebepten Abdülganî b. İsmâil en-Nablusî (ö. 1143/1731), Tâcüddin b. Zekeriyya'nın (ö. 1050/1640) Tâciyye isimli eserinde veciz olarak ifâde ettiği kelimât-ı kudsiyye'yi, faydasının genel olması için şerh etmiştir. Bu îtibarla öncelikle, müellif Tâcüddîn $b$. Zekeriyyâ ve eseri Tâciyye ile şârih Abdülganî b. İsmail en-Nablusî hakkında mâlûmât vermenin doğru olacağı kanaatindeyiz.

\section{Tâcüddîn b. Zekeriyyâ}

\section{1. Hayat1}

Hindistan'ın Delhi şehrinin Senbhel kasabasında 950//1543 yılında dünyâya gelen söz konusu mutasavvıfın tam ismi, Tâcüddîn b. Zekeriyyâ b. Sultân el-Abşemî el-Ümevî el-Osmanî el-Hindî enNakşibendî'dir (ö. 1050/1640). Onun “Osmânî" nisbesi ile anılması, soyunun Hz. Osman'a (r.a.) dayanması sebebiyledir. Abdülkerim esSem'ani'ye göre o, Kureyş'in Abdümenâf oğullarından Abdüşşems koluna mensuptur. ${ }^{1}$

1 Ebû Sa'd Abdülkerîm b. Muhammed b. Mansûr es-Sem'ânî, el-Ensâb, thk. Abdülfettâh Muhammed el-Hulv (Beyrut: y.y., 1981), 8/367-368; Necdet Tosun, 
298 I M. ÖZÇELIK / Abdülğanî b. İsmâil en-Nablusî (ö. 1143/1731) ve Miftâhu'l-Ma'tyye Adlı Eseri Çerçevesinde Nakşibendî Tarikatının On Bir Esâsı

Tâcüddîn b. Zekeriyyâ, halîfelerinden Mahmud b. Eşref elHüseynî'nin naklettiğine göre genç yaşta iken Hızır (a.s.) vâsıtasıyla tevbe etti ve bundan sonra şeyh bulmak maksadiyla birtakım seyâhatlerde bulundu. Bu arayış esnâsında o, henüz şeyhini bulmadan önce bazı şeyhlerin ruhları ile mülâkî oldu, birtakım keşiflere mazhar oldu $^{2}$ ve farklı tarîkatlardan icâzet aldı. O, ilk seyahatinde, Ecmîr şehrine uğrayıp Çiştiyye Tarîkatı'nın kurucusu Muînüddîn el-Çiştî́nin kabrinde inzivâya çekildi ve Çiştî'nin rûhâniyetinden "Hıfzu'l-Enfâs" zikrini tâlim etti. Daha sonra Çiştî̀nin rûhaniyyetinden aldığı emirle Bâkûr şehrine gidip Hamidüddîn Nâgevrî el-Bâkûrî'nin kabrini ziyâret edip onun rûhâniyetinden de Çiştiyye Tarîkatı'nın âdâbını öğrendi. Nizâmüddîn el-Bâkûrî'nin da aralarında bulunduğu birçok şeyhle karşılaştı, ancak hiçbirisine intisâb etmedi. Daha sonra Şeyh İlâhbahş'la tanıştı ve ona intisâb etti. Bir takım ağır riyâzatlarla Şeyh İlâhbahş'tan "Aşkıyye" zikrini tâlim etti. On yıl boyunca Şeyh İlâhbahş'ın hizmetinde bulunduktan sonra ondan Aşkıyye, Kâdiriyye, Çistiyye ve Medâriyye tarîkatlarının icâzetini aldı. ${ }^{3}$

Tâcüddîn b. Zekeriyyâ, Şeyh İlâhbahşs'in vefâtından sonra Lahor'da bulunan "Bâkî Billâh" ismiyle mârûf olan NakşibendiyyeAhrâriyye Tarîkatı'nın şeyhi Muhammed Abdülbâkî'ye (ö. 1012/1603) intisâb edip ondan, üç gün gibi kısa bir süre içinde Nakşibendiyye hilâfeti aldı. On yıl kadar Bâkî Billâh'ın sohbetinde bulunduktan sonra Bâkî Billâh'ın emriyle memleketi Senbhel'e gitti ve irşâdî faaliyetlerine orada devâm etti. ${ }^{4}$ Bâkî Billâh'ın vefâtından sonra Senbhel'den ayrılarak Hindistan, Irak ve Arabistan'ın muhtelif bölgelerinde dolaştı ve en sonunda Mekke-i Mükerreme'ye yerleşti. Orada, takvâsı ile meşhûr olan

Bahaeddin Nakşibend: Hayatı, Görüşleri, Tarikatı (İstanbul: İnsan Yayınları, 2002), 206; Ayşegül Mete, “Nakşibendiyye-Tâciyye'nin Kurucusu: Tâceddîn b. Zekeriyyâ Hayatı, Eserleri ve Tasavvufî Yolu", Türkiyat Araştırmaları Dergisi 32 (2012), 179.

2 Muhammed Emin b. Fazlullah b. Muhibbillah ed-Dımaşkî el- Muhıbbî, Hulâsatü'leser fî a'yâni'l-karni'l-hâdi aşer (Kahire: Matbaatu'l-vehbiyye, 1284), 1/464.

3 Muhibbî, Hulâsatü'l-eser, 1/464-469; Şerîf Abdulhay b. Fahruddîn el-Hasenî, Nüzhetü'l-havâtır ve behcetü'l-mesâmi' ve'n-nevâzır (Beyrut: Dâru İbn-i Hazm, 1420/1999), 507.

4 Hasenî, Nüzhetü'l-havâtır, 507; Reşat Öngören, “Taceddin b. Zekeriyya”, Türkiye Diyanet Vakfi İslâm Ansiklopedisi (Ankara: TDV Yayınları, 1996), 39/342; Mete, "Nakşibendiyye-Tâciyye'nin Kurucusu: Tâceddîn b. Zekeriyyâ Hayatı, Eserleri ve Tasavvufî Yolu", 182. 
Ahmed Allân'ın (ö. 1033/1624) da aralarında bulunduğu birçok kişi kendisine intisâb etti. Daha sonra o, tekrâr Hindistan'a gitti, âilesini ziyâret edip oğluna hilâfet verdi. Bu arada, kendisi gibi Bâkî Billâh'ın halîfelerinden olan İmâm-1 Rabbânî ile buluştu. Lahor, Basrâ ve Lahye şehirlerinde dolaştı. Gittiği yerlerde birçok kişi kendisine intisâb etti. 1050/1641 yılında Mekke'de vefât etti ${ }^{5}$ ve vasiyeti üzerine Kuaykıân Dağı'nın eteklerinde, fakirler ve miskinler için inşâ ettirmiş olduğu tekkeye defnedildi. ${ }^{6}$

Muhıbbî'nin naklettiğine göre o, "İbn Acîl'ler" ismiyle tanınan kabîleden Ebû'l-Vefâ Ahmed b. Acîl ve oğlu Mûsâ, Muhammed Mirzâ b. Muhammed, Ahsâ vâlisi Yahyâ b. Ali Paşa gibi birçok ünlü Tâcüddin b. Zekeriyya'ya intisap etmiştir.?

Tâcüddîn b. Zekeriyyâ, halîfeleri vâsıtasıyla Nakşibendiyye Tarîkatı'nın Hicaz ve Yemen bölgesinde yayılmasını sağladı. Aslında o, Nakşibendiyye'nin Ahrâriyye koluna mensup bir sûfî idi, ancak zamanla kendisine nisbet edilen Tâciyye adında bir şube ortaya çıtı. ${ }^{8}$ Onun silsilesi, Muhammed Abdülbâkî (Bâkî Billâh), Mevlânâ Hâce Emkenâkî, Derviş Muhammed Emkenâkî ve Muhammed Zâhid Vahşî ile Hâce Ubeydullâh-i Ahrâr'a ulaşır. ${ }^{9}$

Şeyh Tâcüddîn b. Zekeriyyâ'nın icâzet verdiği beş halîfesi vardır. ${ }^{10}$ Onun silsilesi, Ebü'l-Vefâ Ahmed b. Muhammed el-Acîl, Seyyid Mahmûd el-Hindî ve Muhammed Abdülbâkı ez-Zebîdî olmak üzere üç ayrı koldan devâm etmiştir. Makalemize konu olan Tâciyye isimli eserin şârihi Abülğanî b. İsmail en-Nablusî (ö. 1143/1731), Seyyid Mahmûd el-

5 Hasenî, Nüzhetü'l-havâtır, 508; Öngören, “Taceddin b. Zekeriyya”, 39/342; Mete, "Nakşibendiyye-Tâciyye'nin Kurucusu: Tâceddîn b. Zekeriyyâ Hayatı, Eserleri ve Tasavvufî Yolu", 183.

6 Muhibbî, Hulâsatü'l-eser, 1/470; Şihâbüddîn Ahmed b. Muhammed el-Mekkî enNahlî, Büğyetü't-tâlibîn li-beyâni'l-meşâyihı'l-muhakkîni'l-mu'temedîn (Haydarabad: Matbaatü meclis-i dâirati'l-meârifi'n-nizâmiyye, 1. Basım, 1328), 80; Hasenî, Nüzhetü'l-Havâtır, 508; Mete, “Nakşibendiyye-Tâciyye'nin Kurucusu: Tâceddîn b. Zekeriyyâ Hayatı, Eserleri ve Tasavvufî Yolu", 194-195.

7 Muhibbî, Hulâsatü'l-eser, 1/508.

8 Öngören, "Taceddin b. Zekeriyya", 39/342.

9 Muhibbî, Hulâsatü'l-eser, 1/469-470; Nablûsî, Miftâhu'l-maiyye, 49.

10 Ayrıntılı bilgi için bk. Mete, “Nakşibendiyye-Tâciyye'nin Kurucusu: Tâceddîn b. Zekeriyyâ Hayatı, Eserleri ve Tasavvufî Yolu", 190-192. 
300 I M. ÖZÇELIK / Abdülğanî b. İsmâil en-Nablusî (ö. 1143/1731) ve Miftâhu'l-Ma'tyye Adlı Eseri Çerçevesinde Nakşibendî Tarikatının On Bir Esâsı

Hindî (ö. 1032/1623) ile devâm eden ve Şeyh İlâhbahş'a uzanan silsile ile Tâcüddîn b. Zekeriyyâ'nın silsilesine mensuptur. ${ }^{11}$

Tâcüddîn b. Zekeriyyâ'nın Âdabü'l-meşîha ve'l-mürîdîn, Vâridâtü Seyh Tâceddin (Tâciyye), Risâle fi'l-cevâbi 'alâ suâli'l-'ulemâa' 'an ba'zi ef'âli'ssûfiyye ve Câmi'u'l-fuâd isimli telif eserleri, Mu'arrebü'r-reşehât ve Ta'ribü'n-Nefehâtü'l-Üns isimli şerhleri ve muhtelif konularda küçük risâleleri bulunmaktadır. Makalemize konu olan Miftâhu'l-ma'ıyye fi düstûri't-Tarîkati'n-Nakşibendiyye isimli eser, Tâcüddîn b. Zekeriyyâ'nın Tâciyye isimli eserini şerh etmektedir.

\section{2. Tâciyye}

Tâceddîn b. Zekeriyyâ'nın, muhtelif sûfîlerden iktibaslar yaparak telif ettiği bu eserin kütüphanelerde farklı isimlerde kayıtları bulunmaktadır. Nefhâtü̈l-ilâhiyye fì Tarîkati'n-Nakşibendiyye (Vâridâtü Şeyh Tâciddîn b. Zekeriyyâ), Risâle fî usûli't-Tarîkati'n-Nakşibendiyye, Risâle fì âdâbi't-Tarîkati'n-Nakşibendiyye bunlardan bazılarıdır. ${ }^{12}$ Nablusî bu eseri, Miftâhu'l-ma'ıyye fî düstûri't-Tarîkati'n-Nakşibendiyye ${ }^{13}$ adıyla şerh etmiştir. Bu şerh, Osman Bahrî b. Muhammed Emîn tarafindan 1289/1881 târihinde Tercüme-i Miftâhü'l-maiyye fì Tarîkati'nNakşibendiyye $e^{14}$ ismiyle Türkçeye tercüme edilmiştir. Eserin mukaddimesinde, Nakşibendî Tarîkatı'nın Ehl-i Sünnet îtikâdı üzerine bir tarîkat olduğuna vurgu yapılır; intisâbın rûhî/mânevî doğum mânâsına geldiği bu yüzden, şeyhin, mürîdin mânevî babası olduğu ifâde edilir. Eser yedi bölüm olarak tanzim edilmiştir. Birinci bölümde, Tâceddin b. Zekeriyâ'nın silsilesi zikredilir ve kaç çeşit şeyh olduğundan bahsedilir. İkinci bölümde, Nakşibendiyye Tarîkatı'nda Allâh Teâlâ'ya ulaşmanın yolları, üçüncü bölümde, Nakşibendiyye Tarîkatı'nın on bir esâsı, dördüncü bölümde, Nakşibendiyye Tarîkatı'nın zâhirî ve bâtınî âdâbı, beşinci bölümde, fenâ ve bekâ kavramları anlatılır. Altıncı bölümde, mürîdin bâtınî âlemindeki ve başka birindeki mânevî

11 Öngören, "Taceddin b. Zekeriyya", 39/342-341; Mete, "Nakşibendiyye-Tâciyye'nin Kurucusu: Tâceddîn b. Zekeriyyâ Hayatı, Eserleri ve Tasavvufî Yolu", 191, 198.

12 Deyatlı bilgi için bk. Öngören, "Tâceddin b. Zekeriyyâ", 39/343.

13 Bu eserin kütüphane kaydı için bk. Abdülgani b. İsmail en-Nablusî, Miftâhü'l-maiyye fì tarîki'n-Nakşibendiyye (Konya: Konya Bölge Yazmalar Kütüphanesi, 3604/1).

14 Bu eserin kütüphane kaydı için bk. İmam Abdülganî en-Nablusi, Tercüme-i Miftâhü'lmaiyye fi tarîkati'n-Nakşibendiyye, çev. Osman Bahri b. Muhammed Emin Şeyhluli, (Ankara: EHT A 30939/EHT A 35408). 
M. ÖZÇELIK / The Eleven Principles of Naqshibandiyya Tariqa in the Framework of Abdulgani b. Ismail an-Nablusi (d. 1143/1731) and Miftâhu'l-Ma'ryye | 301

hastalıkları def etme konusundaki tasarruflarından bahsedilir. Yedinci bölümde ise mürîdin riâyet etmesi gereken âdâbın neler olduğu hakkında bilgi verilir.

\section{Abdülganî b. İsmail en-Nablusî (ö. 1143/1731)}

Nablusî, mîlâdî XVIII. asırda, 5 Zilhicce 1050 (17 Mart 1641) yılında Dımaşk'ta dünyaya geldi ve hayatının büyük bir kısmını burada geçirdi. Elli yaşlarında iken evliyâullâhın kabirlerini ziyâret etmek ve hac farîzasını îfa etmek maksadıyla Dımaşk'tan ayrıldı ve on beş yıla yakın bir süre Lübnan, Filistin, Misır, Hicaz ve Trablus gibi memleketlerde dolaştı. Tekrar Dımaşk'a dönerek hayatının geri kalan kısmını burada geçirdi. Ömrünü ilme adayan Nablusî, 1143/1731 yılında doksan üç yaşında iken Dımaşk' ta vefât etti ve yaşadığı eve defnedildi. ${ }^{15}$

Nablusî, birçok âlim yetiştiren bir sülâleden gelmektedir. Dedelerinden İbrâhim b. İsmâil, bir müddet Kudüs'ün Nablus kasabasında ikâmet ettiği için bu âile, "Nablusî" nisbesiyle meşhûr olmuştur. ${ }^{16}$ Nablusî'nin babası İsmail, Osmanlı Devleti'nin başkenti İstanbul'a gidip gelen aktif bir âlim idi. ${ }^{17}$ Nablusî, ilk eğitimini babasından aldı. Babası ona Kur'ân-1 Kerîm'i ve bazı temel bilgileri öğretti. On iki yaşlarında iken babasını kaybedip yetim kaldı; ancak yetimliği, onun ilim öğrenmesine mâni olmadı. Fikıh ilmini, Şeyh

15 Hayruddîn Ziriklî, el-E'lâm: Kâmûsü terâcimi'l-eşhüri'r-ricâl ve'n-nisâi mine'l-arabi ve'lmüste'ribine ve'l-müsteşrikîn (Beyrut: Dâru'l-ilmi'l-melâyîn, 15. Basım, 2002), 4/32; Ebû'l-Fazl Muhammed Halil el-Murâdî, Silkü'd-dürer fì a'yâni'l-karni's-sân̂̂ aşer (Bağdad: Mektebetü'l-Mesnâ, ts.), 3/31; Cemîl el-A`zam, Ukûdü'l-cevher fî̀ terâcimi men lehüm hamsûne tasnîfen fe-mietü fe-ekser (Beyrut: el-Matba'atü'l-ehliyye, 1326/1908), 48; Abdülğanî b. İsmail en-Nablûsî, Miftâhu'l-maiyye fî düstûri't-Tarîkati'n-Nakşibendiyye, thk. Cevdet Muhammed Ebü'l-Yezîd el-Mehdî (Kâhire: ed-Dâru'l-cûdiyye, 1. Basım, 1429/2008), 19.

16 Ahmet Özel, “Nablusî, Abdülganî b. İsmâil”, Türkiye Diyanet Vakfi İslam Ansiklopedisi (Ankara: TDV Yayınları, 2006), 32/268. Bu konuda detaylı bilgi için bk. Zeliha Öteleş, Abdülganî en-Nâblusî Şerhi Bağlamında İbnü'l-Fârı'ın Kasîde-i Tâiyye'sinde Seyr u Sülûk, (İstanbul: Marmara Üniversitesi, Sosyal Bilimler Enstitüsü, Doktora Tezi, 2014), 117.

17 Murâdî, Silkü'd-dürer, 3/31; Cemîl el-'Azam, Ukûdü'l-cevher, 48. (Abdüğanî'nin babası, Abdülganî henüz doğmadan İstanbul'da bulunmaktaydı. Şeyh Mahmûd adında meczûb ve sâlih bir zât, hanımına, hâmile olduğunu söylemiş; ona bir gümüş para vererek doğacak olan çocuğun adını Abdülğanî koymasını tembihlemiş ve doğacak olan çocuğun bir takım ilâhî yardımlara mazhar olacağını haber vermiş. Gerçekten de Şeyh Mahmud'un söylediği tarihte Abdülganî dünyâya gelmiş. (Murâdî, Silkü'ddürer, 3/31; Cemîl el-'Azam, Ukûdü'l-cevher, 48.) 
302 I M. ÖZÇELIK / Abdülğanî b. İsmâil en-Nablusî (ö. 1143/1731) ve Miftâhu'l-Ma'ryye Adlı Eseri Çerçevesinde Nakşibendî Tarikatının On Bir Esâsı

Ahmed el-Kal'î el-Hanefî' den (ö. 1067/1657); nahiv, meânî, beyân ve sarf ilimlerini, zamanının sâlih ve zâhid ulemâsının önde gelenlerinden Molla Mahmûd el-Kürdî'den (ö. 1074/1663); hadîs ilmini, Şeyh Abdülbâkî el-Hanbelî́den; tefsîr ilmini ise Şeyh Muhammed b. Tâcüddîn b. Zekeriyyâ b. Ahmed el-Mehâsinî'den (ö. 1072/1661) öğrendi. Nablusî, sâdece sözü geçen âlimlerden ilim tahsil etmekle yetinmeyip onların dişında, Necmüddîn Muhammed b. Muhammed elĞazzî (ö. 1061/1651), Şeyh Muhammed b. Ahmed el-Üstüvânî (ö. 1072/1661), İbrâhîm b. Mansur el-Fettâl (ö. 1098/1687) ve Şeyh Abdülkadir b. Mustafa es-Sufûrî (ö. 1081/1671) gibi daha birçok âlimin ders halkasına katılıp onlardan icâzet aldı ve nihâyet zâhirî ilimlerin tamamında söz sâhibi bir âlim oldu. ${ }^{18}$

Nablusî, bütün bu ilimleri tahsil edip bitirdiğinde henüz yirmi yaşlarında bir delikanlı idi. Zâhirî ve bâtınî ilimlerdeki dirâyeti sâyesinde eser telif etmeye ve Emevî Câmii'nde dersler vermeye başladi. $\mathrm{O}$, bir taraftan eser yazarken bir taraftan da Muhyiddin İbn Arabî, İbn Seb'în, Afîf et-Tilimsânî gibi meşhur sûfilerin eserlerini tetkik ediyordu. $\mathrm{Bu}$ tetkikler neticesinde onda, bir takım mânevî haller zuhûr etmeye başladı. Bu hallerin tesiriyle aşka dâir şiirler ve Rasûlüllâh (s.a.v.) için methiyeler yazd. ${ }^{19}$

Nablusî, sâdece zâhirî ilimleri tahsil etmekle iktifâ etmeyip tasavvufa yöneldi. İstanbul yolculuğu sırasında Hama şehrinde Kâdirî şeyhi Seyyid Abdürrezzak el-Hamevî el-Geylânî vâsitasıyla Kâdiriyye hırkası, sonra da aslen Buhâralı olan Şeyh Saîd el-Belhî (ö. 1092/1681) vâsıtasıyla Nakşibendiyye hırkası giydi. ${ }^{20}$ 1091/1680 senesinde kırk yaşında iken toplumun yozlaşmasını, küfrün ve putperestliğin yaygınlaşmasını gerekçe göstererek ${ }^{21}$ yedi yıl süreyle halvete çekildi ve zarûrî ihtiyâçlar hâricinde hiç dışarıya çıkmadı. Bununla beraber

18 Murâdî, Silkü'd-dürer, 3/31; Cemîl el-'A'zam, Ukûdü'l-cevher, 48-49; Öteleş, Abdülgan̂̂ en-Nâblusî Şerhi Bağlamında İbnü'l-Fârız'ın Kasîde-i Tâiyye'sinde Seyr u Sülûk, 117-118.

19 Murâdî, Silkü'd-dürer, 3/31-32.

20 Murâdî, Silkü'd-dürer, 3/31; Özel, “Nablusî, Abdülganî b. İsmâil”, 32/268; Bekri Alâaddin, Bir Çağın Öncüsü Abdülganî Nâblusî Hayâtı ve Fikirleri, çev. Veysel Uysal (İstanbul: İnsan yayınları, 1995), 103-105.

21 Bununla beraber bazıları, Nablusî'nin geçirmiş olduğu rûhî bir bunalımdan dolayı inzivâya çekildiğini söylemiş; bazıları ise bu inzivânın sebebini kara sevda olarak göstermiştir. Hatâ onun hakkında beş vakit namazı kılmadığı yönünde sözler sarf edenler; ona yakışmayan sözler sarf edenler olmuştur. (Murâdî, Silkü'd-dürer, 3/32.) 
M. ÖZÇELIK / The Eleven Principles of Naqshibandiyya Tariqa in the Framework of Abdulgani b. Ismail an-Nablusi (d. 1143/1731) and Miftâhu'l-Ma'ryye I 303

Nablûsî'nin inzivâ hayatı, bilinen inzivâ hayatından farklılık arz etmekteydi. Çünkü o, halvette iken sadece ibâdet ve evrâd ü ezkâr ile meşgûl olmuyor; bir taraftan Kur'ân-1 Kerîm'i derinlemesine inceliyor; bir taraftan hüsn-i hat ile meşgûl oluyor; bir taraftan civârındaki tasavvuf erbâbı ile alâkadâr oluyor; bir taraftan sinırlı sayıdaki dostlarına dersler veriyor; bir taraftan da eser telifi ile meşgûl oluyordu..$^{22}$

İslamî ilimlerin her türünde söz sâhibi olan Abdülganî en-Nablusî, daha çok tasavvufî kimliği ile meşhûr olmuştur. Onun telif ettiği eserlerin çoğunluğu ${ }^{23}$ tasavvufla ilgili ve "vahdet-i vücûd" düşüncesini anlatan kitapların şerhi mâhiyetindedir. Yaşadığı çağda Suriye'nin mânevî hayatına yön veren önemli mutasavvıflar arasında bulunmasına ve tasavvufî konularda derin vukûfiyet sâhibi olmasına rağmen Nablusî'ye nispet edilen müstakil bir tarîkat bulunmamaktadır. Nablusî, mutasavvıf kimliği ile temeyyüz etmiş olsa da fıkıh, kelâm, tefsîr ve edebiyat sahasında da kendisini geliştirmiştir. Onun kelâmî görüşleri, ${ }^{24}$ Ehl-i Sünnet çizgisi dişına taşmaz. Bazı husûslarda Ehl-i Sünnet'in iki büyük imâmı İmam Eş'arî ve İmam Mâtürîdî'nin görüşlerini telif etmeye çalıştığı görülür. Bunların dışında o, astronomi, coğrafya, mûsikî, tıp ve ziraat gibi farklı alanlarda da eserler telif etmişş çok yönlü bir Osmanlı âlimidir. ${ }^{26}$

22 Murâdî, Silkü'd-dürer, 3/32; Şeyh Yûsuf b. İsmâil en-Nebhânî, Câmi'u Kerâmâti'lEvliyâ, thk. İbrâhim Atve Ivaz (Porbandar: Merkez-i Ehli Sünnet Berakât-i Razâ, 1422/2001), 2/194-195; Özel, “Nablusî, Abdülganî b. İsmâil”, 32/268.

23 Eserleri için bk. İsmail Bağdâdî, Hediyyetü’l-ârifinn (İstanbul: y.y., 1951), 1/591-594; Murâdî, Silkü'd-dürer, 3/32-37; Ziriklî, el-A'lâm, 4/32-33.

24 Nablusî’nin kelamî görüşleri hakkında geniş bilgi için bk. Ahmet Kamil Cihan, Abdülganî Nâblusî'nin Hayâtı ve Kelâmî Görüşleri (Kayseri: Erciyes Üniversitesi, Sosyal Bilimler Enstitüsü, Yüksek Lisans Tezi, 1988.)

25 Özel, "Nablusî, Abdülganî b. İsmâil”, 32/268. (Bu konuda detaylı bilgi için bk. Öteleş, Abdülganî en-Nâblusî Şerhi Bağlamında İbnü'l-Fârzz'ın Kasîde-i Tâiyye'sinde Seyr u Sülûk, 119-120.)

26 Nablûsî, Osmanlı Devleti'ne ve Türklere muhabbet eden bir âlimdir. Bu muhabbetin bir göstergesi olarak o, tüm Osmanlı hânedanına, Türk sultanlarına ve özellikle İslâm ümmetine yaptığı hizmetleri sebebiyle II. Ahmed'e manzum duâ tarzında methiyeler yazmıştır. (Mehmet Sait Toprak, “İnsan'ın Anlamı Üzerine Bir Araştırma: Abdülganî en-Nablusî”, Dokuz Eylül Üniversitesi İlahiyat Fakültesi Dergisi 26 (2007), 49.) 
304 | M. ÖZÇELIK / Abdülğanî b. İsmâil en-Nablusî (ö. 1143/1731) ve Miftâhu'l-Ma'ryye Adlı Eseri Çerçevesinde Nakşibendî Tarikatının On Bir Esâsı

\section{Nakşibendiyye Tarîkatı'nın On Bir Esâsı}

"Kelimât-1 Kudsiyye" diye tâbîr edilen Nakşibendiyye Tarîkatı'nın on bir esası, yaygin kanaate göre Bahâüddîn Şah-1 Nakşibend'in (ö. 791/1389) üveysî yoldan mürşidi olan Abdülhâlık-1 Gucdüvânî (ö. 612/1220) tarafından tesis edilmiştir. ${ }^{27}$ Bununla beraber, bu kaidelerden ilk sekizinin Abdülhâlk-1 Gücdüvânî tarafından, son üçünün ise Bahâüddîn Şah-1 Nakşibend tarafından tesis edildiğini söyleyenler de olmuştur. ${ }^{28}$ Farsça olarak kalıplaşmış bu on bir kelime, Nakşibendiyye Tarîkatı'na mensup olan müritlerin günlük hayatta ve zikir esnâsında riâyet etmeleri gereken kâideleri ifâde eder. ${ }^{29}$ Bunlar, Hûş Der Dem, Halvet Der Encümen, Nazar Ber Kadem, Sefer Der Vatan, Yâd Kerd, Bâz Geşt, Nigâh Daşt, Yâd Dâşt, Vukûf-i Zamânî, Vukûf-i Adedî, Vukûf-i Kalbî olarak ifâde edilmektedir.

Muhammed Bâkî Billâh'ın (ö. 1012/1603) mânevî terbiyesinde yetişen ve yaptığı seyahatleri ile Nakşibendiyye'nin Hindistan, Ortadoğu ve Hicaz bölgesinde yayılmasını sağlayan Taceddin $b$. Zekeriyyâ (ö. 1050/1640), Tâciyye isimli eserinin bir bölümünü Nakşibendiyye'nin on bir esâsına ayırmıştır. Biz de bu bölümde, Abdülganî b. İsmail Nablusî'nin (ö. 1143/1731) Tâciyye'ye şerh olarak yazdığı Miftâhu'l-ma'ıyye isimli eserindeki Nakşibendiyye'nin on bir esâsı ile ilgili bölümünü inceleyeceğiz.

\section{1. Esâs: Yâd Kerd}

Yâd kelimesi, zikretmek/hatırlamak mânâsına gelmektedir. Istılâhî olarak ise mürîdin, mürâkabe mertebesine ulaştıktan sonra, dili ile nefy ve isbâtı, yani "Lâ ilâhe illellâh" zikrini her gün belli bir adet kadar söylemesidir. Bu mertebede dil ile yapılan nefy ve isbât zikri, bir

27 Nablûsî, Miftâhu'l-maiyye, 99; H. Kâmil Yılmaz, Anahatlarıla Tasavouf ve Tarîkatlar (İstanbul: Ensar Neşriyat, 11. Basım, 2007), 290; Osman Türer, Ana Hatlarıla Tasavouf Tarihi (İstanbul: Seha Neşriyat, 1998), 179; Muhammed Ahmed Dernîka, et-Tarîkatü'nNakşibendiyye ve a'lâmühâ (Trablus: Jarrous Press, 1408/1987), 24.

28 Dernîka, et-Tarîkatü'n-Nakşibendiyye ve a'lâmühâ, 25; Tosun, Bahaeddin Nakşibend, 334; Tosun, "Nakşibendiyye" (Âdâb ve Erkân), Türkiye Diyanet Vakfı İslâm Ansiklopedisi (Ankara: TDV Yayınları, 2006), 32/342; Murat Özaydın, "Şeyh Abdurrahman'a Göre Nakşibendîliğin On Bir Temel Esası", Elektronik Sosyal Bilimler Dergisi 13/50 (2014), 214. (Kelimât-ı Kudsiyye'nin sırası konusunda farklılıkların olduğu görülmektedir. Ancak Şah-1 Nakşibend'in tesis ettiği söylenen son üç kâide, Vukûf-i Zamânî, Vukûfi Adedî ve Vukûf-i Kalbî'dir.)

29 Tosun, Bahaeddin Nakşibend, 334. 
M. ÖZÇELIK / The Eleven Principles of Naqshibandiyya Tariqa in the Framework of Abdulgani b. Ismail an-Nablusi (d. 1143/1731) and Miftâhu'l-Ma'ryye I 305

müddet sonra kalbin nurlanmasına vesile olacaktır. Çünkü kalp, bedenin diğer organları ile daima irtibat halindedir. Murâkabe mertebesinden müşâhede mertebesine geçildiğinde ise zikrin dil ile veya kalp ile yapılması veya zikredilen lafzın kelime-i tevhid veya başka bir şey olması fark etmez. ${ }^{30}$ Bu şekildeki zikrin nihâî gâyesi, kalbin mâsivâ ile alâkasını keserek dâimî sûrette Allâh Teâlâ'yı zikretmesini sağlamaktır. ${ }^{31}$ Bazılarına göre yâd kerd kelimesi, nefesi tutarak kelime-i tevhîd zikri yapmayı ifâde etmektedir. Bu düşüncede olanlara göre yâd kerd yapmaktan maksat, kalpte ârız olan perdeleri ve mâniaları def edip kalbi, aslî sûretine döndürmek ve kalbe remz edilmiş olan ilâhî tecellîlerin nurlarını açı̆̆a çıkarmaktır ki, bu da kalbin tasfiye edilip nurlanmasından ibârettir. ${ }^{32}$

Tâcüddîn b. Zekeriyyâ'ya göre bu tâbir, dil ve kalp ile devamlı sûrette Allâh Teâlâ'nın zikredilmesini ifâde eder. Buna göre müridin, şeyhinin kendisine tâlim etmiş olduğu husûsi zikri, Hak Teâlâ'nın huzûrunda olduğu idrâkini kesb edinceye kadar devamlı olarak tekrâr etmesi gerekmektedir. 33

Nakşibendiyye Tarîkatı'nda zikir, şu şekilde icrâ edilir. Önce şeyh, kalben kelime-i tayyibeyi ${ }^{34}$ zikreder; mürîd, kalbini, şeyhin kalbinin karşısındaymış gibi tasavvur eder; gözlerini açıp ağzını kapatır. Çünkü Hâce Bahâüddîn "Zikirden maksat, kalbin, muhabbet ve tâzîm vasfı ile

30 Muhammed b. Abdullah el-Hânî, el-Behcetü's-seniyye fî âdâbi-Tarîkati'l-Aliyyeti'lHâlidiyyeti'n-Nakşibendiyye (İstanbul: İhlas Vakfı Yayınları, 1381/2002), 94; Abdülmecîd b. Muhammed el-Hânî, el-Kevâkibü'd-dürriyye ale'l-Hadâikı'l-Verdiyye fî ecillâi's-sâdâti'n-Nakşibendiyye, tsh. Muhammed Halid el-Harse (Dımaşk: Dâru'lBeyrûtî, 1996), 365.

31 Dernîka, et-Tarîkatü'n-Nakşibendiyye ve a'lâmühâ, 25; Türer, Ana Hatlarıla Tasavouf Tarihi, 181; Tosun, Bahaeddin Nakşibend, 337; Yılmaz, Anahatlarıla Tasavouf ve Tarîkatlar, 292.

32 Nasrullah Bahaî, Büyük İslâm Velîsi Muhammed Bahaeddin Şah Nakşibendî Hayâtı, Şahsiyeti, Menkibeleri, nşr. Taşköprülü Ali Altın (İstanbul: M. Şevket Eygi Matbaası, 1328/1966), 115-116.

33 Nablûsî, Miftâhu'l-maiyye, 102.

34 Kelime-i Tayyibe, Kur'ân-1 Kerîm'de, "Görmedin mi, Allâh nasıl bir misâl getirdi: Kelimei tayyibe'yi (güzel bir sözü), kökü (yerde) sâbit, dalları gökte olan güzel bir ağaca (benzetti.)" (İbrâhîm, 14/24.) âyet-i kerîmesinde geçmektedir. İbn Abbas (r.a.) "kelime-i tayyibe" ile kastedilen şeyin, Allâh'tan başka ilâh olmadığını ifâde eden "Lâ ilâhe illellâh" sözü olduğunu söylemiştir. (Bk. Muhammed Ali es-Sâbûnî, Safvetü't-tefâsîr (Beyrut: Dâru'l-Kalem, 1980), 2/96.) 
306 I M. ÖZÇELIK / Abdülğanî b. İsmâil en-Nablusî (ö. 1143/1731) ve Miftâhu'l-Ma'tyye Adlı Eseri Çerçevesinde Nakşibendî Tarikatının On Bir Esâsı

dâimî sûrette Allâh Teâlâ'nın huzûrunda bulunmasıdır. Çünkü zikir, gafletin kovulmasından ibârettir." demiştir. ${ }^{35}$

Nablusî'ye göre mürîdin, kendi kalbini, şeyhinin kalbi karşısındaymış gibi tasavvur etmesi şu şeklide olmalıdır:

Mürîd, kendisini, şeyhin huzûrunda iki dizinin üstünde oturur vaziyette tasavvur eder ve kalbi ile şeyhin kalbini mülâhaza eder. Bu esnada mürîd, şeyhin meclisi dışında hiçbir şeyin varlığını kalbine getirmemelidir. Nablusî̀ye göre bu husûs, mürîdin şeyhinden tam mânâda istifâde etmesi için çok büyük ehemmiyet arz eder. Nitekim İbn Arabî'nin kadın şeyhlerinden Fâtıma b. Müsennâ, İbnü'l-Arabî gibi kendisinin huzûruna hiçbir kimsenin gelmediğini söylemiş. Bunun nedeni sorulunca İbnü'l-Arabî dişındakilerin, vücutlarının bir kısmını, evlerinde ve âilelerinde bırakarak geldiklerini; ancak İbnü'l-Arabî'nin ise bütün varlığ1 ile huzûruna gelip bütün varlığı ile huzûrundan çıktığını söylemiştir. Nablusî, bu düşünceden hareketle her müridin şeyhinin huzûruna tüm varlığı ile gelip durması gerektiğini söyler. Şeyhinin huzûrunda duran mürîd bu esnâda gözlerini açıp ağzını kapatmalıdır. Gözlerin açılması, mürîdin karşısındaki şeyhinin sûretine bakması içindir. Çünkü şeyhin yüzüne bakmak, "zikr-i kalbî”nin husûle gelmesine sebep olur. Ağzın kapanması ise mürîdin, şeyhin kalbini mülâhaza etme esnâsında, yanlışlıkla zikr-i cehrî yaparak şeyhin yapmakta olduğu zikr-i hafîye muhâlefet etmemesi içindir. Zikirden maksat, kalbin, dâimâ Allâh Teâlâ'nın huzûrunda olduğunu idrâk etmesini sağlamaktır. Bu idrâk oluştuktan sonra mürîd, dil ile zikretmekten müstağnî olmuş olur. Çünkü zikirden maksat, kalpten gafletin kovulmasıdır. Kalbin her dâim Allâh Teâlâ'nın huzûrunda olduğunu hissetmesi hâlinde zaten gafletten eser kalmamış ve maksat hâsıl olmuş demektir. ${ }^{36}$

\section{2. Esâs: Bâz Geşt}

Bu tâbir, zikir esnasında kendiliğinden hatıra gelen iyi ya da kötü düşünceyi def etmek mânasında kullanılmaktadır. ${ }^{37}$ Lügatte "geri dönmek, vaz geçmek, tekrarlamak", 38 "bir makamdan başka bir makama

35 Nablûsî, Miftâhu'l-maiyye, 102.

36 Nablûsî, Miftâhu'l-maiyye, 102-103.

37 Yılmaz, Anahatlarıla Tasavouf ve Tarîkatlar, 293.

38 Süleyman Uludağ, "Bâz-geşt", Tasavvuf Terimleri Sözlüğ̈̈ (İstanbul: Kabalcı Yayınları, 2005), 69. 
dönmek" gibi manalara gelen bu tabir ile kastedilen, önce nefesini tutarak kalbiyle nefy ve isbât zikrini yapan mürîdin, daha sonra nefesini salarak dili ile "İlâhî ente maksûdî ve rizâke matlûbî" zikrini söylemeye dönmesidir. Mürîdin sürekli bu zikri tahayyül etmesi, nefy ve isbat zikrinin manasının pekişmesini sağlayacaktır. Bu durumda mürîd, tevhid-i hakîkînin sırrına vâkıf olacak ve nihâyet, vâhid-i mutlak olan Allâh Teâlâ'nın varlığından başka hiçbir varlığı görmez olacaktır. ${ }^{39}$

"Bâz geşt" tâbirinin, mürîdin, zikir esnâsında acziyet ve kusurlarını îtiraf ederek nefsinden uzaklaşıp Allâh Teâlâ'ya dönmesini ifâde ettiğini söyleyenler de olmuştur. Çünkü kul, ancak Allâh Teâlâ'nın yardımı sâyesinde O'nu zikretmeye muktedir olabilir. "Seni hakkıyla zikredemedik Ey mezkûr olan (Allâh'ım)" sözü, işte bu mânaya işâret etmektedir. ${ }^{40}$

Tâcüddîn b. Zekeriyyâ bu tâbîrin, zikreden kişinin, kalbi ile kelime$i$ tayyibeyi her zikrettiğinde, hemen akabinde dili ile de "Ey Allâh'ım! Maksadım Sen'sin, isteğim ise senin rızandır." demesini ifâde ettiğini söyler. Ona göre bu şekilde yapılan zikir, akla gelen güzel ya da çirkin her türlü düşüncenin ortadan kaybolmasını sağlar. ${ }^{41}$

Nablusî̀ye göre Allâh Teâlâ'nın kulundan râzı olması, O'nun murâdının, kulun murâdına tercîh edilmesine râcidir. Bu tercîh, kulun, rızâ-i ilâhîyi, Allâh Teâlâ'nın azâbından kurtulmaktan, cennetin lezzetlerine ve bol sevaplara nâil olmaktan, bütün ihtiyaçlarının karşılanmasından; hâsılı kulun hoşuna gidecek her şeyden daha üstün görmesini iktizâ eder. Kulun, Cenâb-1 Hakk'ı bu şekilde zikretmesi, zikir esnâsında kulun kalbine gelebilecek her türlü müsbet ve menfî düşüncenin izâle edilmesini sağlayacaktır. Çünkü zikir esnâsında kalbe gelen her türlü düşünce, kalbi, zikirden alıkoyacak ve onun Allâh Teâlâ'dan yüz çevirmesine sebep olacaktır. Bu yüzden zikir esnâsında kalbe gelen düşünceler, güzel bile olsa kınanmıştır. ${ }^{42}$

39 Hânî, el-Behcetü's-seniyye, 95; Hânî, el-Kevâkibü'd-dürriyye, 366; Yılmaz, Anahatlarryla Tasavvuf ve Tarîkatlar, 292; Türer, Ana Hatlarıla Tasavouf Tarihi, 181; Tosun, Bahaeddin Nakşibend, 337; Bahaî, Büyük İslâm Velîsi Muhammed Bahaeddin Şah Nakşibendî, 117.

40 Hânî, el-Behcetü's-seniyye, 95; Hânî, el-Kevâkibü'd-dürriyye, 366-367; Dernîka, etTarîkatü'n-Nakşibendiyye ve a'lâmühâ, 27.

41 Nablûsî, Miftâhu'l-maiyye, 104.

42 Nablûsî, Miftâhu'l-maiyye, 104. 
308 I M. ÖZÇELIK / Abdülğanî b. İsmâil en-Nablusî (ö. 1143/1731) ve Miftâhu'l-Ma'tyye Adlı Eseri Çerçevesinde Nakşibendî Tarikatının On Bir Esâsı

Bu hâl, zikrin hâlis bir zikir seviyesine çıkıncaya ve zikreden mürîdin, Allâh Teâlâ dışındaki bütün varlıklardan tam mânâsıyla alâkasını kesinceye kadar devâm etmelidir. Bu yüzden zikirle meşgûl olan mürid, kelime-i tayyibeyi ve "Ey Allâh'ım! Maksadım Sen'sin, isteğim ise senin rızandır." münâcâtını söylerken kalbinde bir ihlâs hissetmiyorsa hemen zikri birakmamall; taklit yolu ile de olsa zikre devâm etmelidir. Çünkü zikir, taklit yoluyla da olsa bir müddet sonra Allâh'ın izniyle kalpte ihlâs sıfatının husûle gelmesine sebep olacaktır. ${ }^{43}$

Nablusî'ye göre zikrin hâlis bir zikir hâline gelmesi onun, ancak Allâh Teâlâ dışındaki varlıkların mânevî bulanıklıklarından arındırılması ile mümkündür. Zikreden mürîdin Allâh Teâlâ dışındaki varlıklardan tamâmen alâkasını kesmesi onun, Allâh Teâlâ'nın huzûruna müteveccih bir şekilde ezel fezâsında tayarân etmesini ve melekût âleminde dolaşmasına mâni olacak bütün engellerin ortadan kalmasını sağlar. Zikreden kimsenin, yapmış olduğu zikirlerde kalbinde ihlâs duygusunu bulamaması, onu zikirden uzaklaştırmamalıdır. Çünkü kulun zikir esnâsında tam mânâsıyla kalbini zapt edip sırrını muhâfaza etmeye kudreti yoktur. Bunun sebebi ise insanın cismânî yönünün, rûhanî yönüne gâlip gelmesidir. $\mathrm{O}$ halde mürîde düşen, mürşidini taklit etmek sûretiyle de olsa Allâh'ın izniyle ihlâsı elde edinceye kadar zikre devâm etmektir. ${ }^{44}$

\section{3. Esâs: Nigâh Daşt}

"Nigâh" kelimesi, "muhâfaza etmek" mânâsina gelir. Bu tâbîr ile kastedilen, mürîdin, Allâh Teâlâ'nın zikrine mâni olacak herhangi bir havâtırın ${ }^{45}$ kalbe gelmesini engellemek için zikir esnâsında "nefy" ve

43 Nablûsî, Miftâhu'l-maiyye, 104.

44 Nablûsî, Miftâhu'l-maiyye, 105.

45 Havâtır kelimesi düşünce, kanâat, tasavvur, inanç, tahmin, gönül, idrâk gibi anlamları ihtivâ eden Hâtır kelimesinin çoğuludur. Havâtır ıstılahta, insanın kalbine gelen bir hitap, iç âlemden işitilen bir ses, kalbe gelen bir mesaj/îkâz gibi mânâlarda kullanılır. (Abdülkerîm Kuşeyrî, er-Risâletü'l-Kuşeyriyye, tsh. Hânî el-Hâc (Kâhire: elMektebet't-tevfîkıyye, ts.), 156; Uludağ, "Hâtır", Tasavouf Terimleri Sözlü̆̆̈̈, 160). Havâtır, farklı kaynaklardan gelebilir ve kaynağına göre farklı isimler alır. Şöyle ki, havâtır bazen melek vâsıtasıyla Allâh Teâlâ tarafından gelir ve "ilhâm" adını alır; bazen nefis tarafından gelir ve "hevâcis" (gizli fısıltı/desîse) adını alır; bazen de şeytân tarafından gelir ve "vesvese "adını alır. (Kuşeyrî, er-Risâle, 156; Ebû Tâlib Muhammed b. Ali el-Mekkî, Kûtü'l-kulûb fì mu'âmeleti'l-mahbûb (Beyrut: Dâru'l-fikr, ts.), 1/126.) 
M. ÖZÇELIK / The Eleven Principles of Naqshibandiyya Tariqa in the Framework of Abdulgani b. Ismail an-Nablusi (d. 1143/1731) and Miftâhu'l-Ma'ryye I 309

"isbât"ın yani kelime-i tevhîdin mânâsını mülâhaza ederek kalbini muhâfaza etmesidir. Bir anlık bile olsa kalbin, havâtıra karşı korunması, sûfîler nazarında çok büyük bir iş olarak görülmüştür. "Kim ki, buna güç yetirebilirse, tasavvuf ahlâkı ile ahlaklanmış demektir. Çünkü tasavvuf kalbi, havâtırın girişine karşı korumak ve onu, lüzumsuz düşüncelerden boşaltmak demektir. Kim bu iki husûsa güç yetirebilirse kalbinin hakîkatini bilmiş demektir. Kim de kalbinin hakîkatini bilmiş ise rabbini bilmiş demektir. 'Her kim nefsini tanımışsa Rabbini tanımıştır.' ${ }^{46}$ hadîs-i şerîfi, işte bu hakîkate işâret etmektedir. ${ }^{47}$

Bazılarına göre nigâh dâşt, "Hakk'ın tecelligâhı olan kalp evine, O'nun yüce zâtına yabancı şeylerin, uygunsuz hâtıraların girmesini önlemektir." 48

Nigâh daşt kelimesinin, ifâde ettiği kalbin havâtırdan temizlenmesi, Allâh Teâlâ'nın, kalbi, zâtının cemâline ayna edinmiş olmasından dolayı çok önemlidir. Binâenaleyh kalbini havâtıra karşı muhâfaza edemeyen kişi onda, "Allâh Teâlâ'nın cemâlini, envârını, esmâsını ve sıfatını müşâhede edemez." Bu yüzden kalbin havâtıra karşı muhâfaza edilmesi, Nakşibendiyye yolunda, çok yüksek bir makâm olarak addedilmiştir. ${ }^{49}$

Tâcüddîn b. Zekeriyyâ'ya göre bu tâbîr, müridin, içinden kelime-i tayyibeyi defâlarca tekrâr ederken kalbine gelen havâtırı mürâkabe altında tutmasını ifâde etmektedir. Bu mürâkabe, mürîdin, bir veya iki sâat boyunca herhangi bir düşünceyi veya bir başkasının düşüncesini kalbine getirmemeye çalışması şeklinde olur. Bu şekilde bir mürâkabe, büyük zâtlar ve bazı kâmil evliyalar nazarında önemli bir iştir. Zîrâ kalbin havâtırdan engellenmesi, ancak bu sâyede mümkündür. ${ }^{50}$

46 Bu sözün Yahyâ b. Muâz er-Râzî’ye (ö. 258/871) veya Ebû Saîd el-Harrâz'a (ö. 277/890 [?]) âit olduğu söylenir. Bununla beraber Şâfiî fakîh Maverdî'nin (ö. 450/1058) Edebü'dDünyâ ve'd-dîn adlı eserinde Hz. Aişe'nin, Rasûlüllâh'a (s.a.v.) "İnsan Rabbini ne zaman tanır?" diye sorduğu, onun (s.a.v.) da, "Kendini bildiği zaman" diye cevap verdiği rivâyeti bulunmaktadır. (Teferruatlı bilgi için bk. Muhittin Uysal, Tasavouf Kültüründe Hadis (Konya: Yediveren Yayınları, 2001), 326.)

47 Hânî, el-Kevâkibü'd-dürriyye, 367; Hânî, el-Behcetü's-seniyye, 95-96; Dernîka, etTarîkatü'n-Nakşibendiyye ve a'lâmühâ, 25; Tosun, Bahaeddin Nakşibend, 337.

48 Yılmaz, Anahatlarıla Tasavouf ve Tarîkatlar, 293; Türer, Ana Hatlarıla Tasavvuf Tarihi, 181.

49 Bahaî, Büyük İslâm Velîsi Muhammed Bahaeddin Şah Nakşibendî, 119.

50 Nablûsî, Miftâhu'l-maiyye, 106. 
310 I M. ÖZÇELIK / Abdülğanî b. İsmâil en-Nablusî (ö. 1143/1731) ve Miftâhu'l-Ma'tyye Adlı Eseri Çerçevesinde Nakşibendî Tarikatının On Bir Esâsı

Nablusî'ye göre havâtır, hayır ve şer konusunda kalbe gelen bir takım mânâlar/düşünceler demektir. Bu havâtıra mâni olmak, kelime-i tayyibenin defalarca tekrâr edilmesine ve zihne hiçbir duygu ve düşüncenin getirilmemesine bağlıdır. Çünkü kalpte bir şeyden başkasına yer yoktur. Bu îtibârla kalp bir şeyi zikrettiği zaman ister istemez o şeyin dişındaki şeyleri zikretmekten gâfil olur. Bu yüzden mürîd, kalbine gelen havâtırı def etmeyi alışkanlık hâline ve nihâyet kalbini celâl-i ilâhînin ve cemâl-i ilâhînin nurlarına hâzır hâle getirinceye kadar bir ya da iki sâat mürâkabeye devâm etmelidir. İste bu minvâl üzerine icrâ edilen mürâkabe, Allâh Teâlâ'nın yoluna sülûk etmiş olan büyük şeyhler ve bazi ${ }^{51}$ kâmil evliyâlar indinde çok ehemmiyeti olan bir iştir. Çünkü kulun kalbinden havâtırı def edip ilâhî cezbe âlemine dâhil olması, ancak bu sâyede mümkün olur. ${ }^{52}$

\section{4. Esâs: Yâd Dâşt}

Bu tâbîr mürîdin, nefy ve isbât zikrini yaptığ 1 esnâda nefesini tutarak kalbini koruması ve Allâh Teâlâ'nın huzûrunda olduğunun farkına varmasını ifâde etmektedir. Bu tâbîr, ifâde ettiği mânâ îtibâriyle mürâkabe, sohbet, râbıta kavramları ile benzerlik arz etmektedir..$^{53}$

Yâd dâşt, dil ile zikretmeksizin Allâh Teâlâ'ya dönüş hâlini muhâfaza etmek, zikirde mübalağa ederek Cenâb-1 Hakk'ın huzûrunda bulunmak, O'nu müşâhede etme makâmına erişmek ${ }^{54}$ ve dâimî sûrette Allâh'1 hatırlama hâlinde olmak ${ }^{55}$ gibi mânâları da içermektedir.

Yâd dâşt kelimesinin muktezâsınca hareket eden bir sâlik, kalbinden bütün bağları söküp atmall; bütün kuvvet ve hislerden soyutlanmalı; bütün mevcûdâtı, adem-i asliyyelerine ircâ etmeli yani onları, yaratılmadan önceki gibi "yok" olarak görmeli ve Allâh Teâlâ'nın varlığını, nicelik ve nitelikten, renkten ve şekilden, cihetten ve

51 Nablûsî, bazı evliyânın, zikir esnâsında, kalbe gelen havâtırı mürâkabe etmeye gerek görmediklerini; onların sâdece zikir ile meşgûl olunması yönünde kanâat bildirdiklerini söyler. Onlara göre önemli olan Allâh Teâlâ'nın zikredilmesidir. Bu zikir esnâsında kalbe gelen havâtır bir müddet sonra kendiliğinden kesilecektir. Bu yüzden mürîd, ayrıca havâtırı engellemeye çalışmamalı; sâdece zikr-i ilâhî ile meşgûl olmalıdır. (Bk. Nablûsî, Miftâhu'l-maiyye, 106.)

52 Nablûsî, Miftâhu'l-maiyye, 106.

53 Hânî, el-Kevâkibü'd-dürriyye, 368; Hânî, el-Behcetü's-seniyye, 96; Dernîka, et-Tarîkatü'nNakşibendiyye ve a'lâmühâ, 28.

54 Yılmaz, Anahatlarıla Tasavouf ve Tarîkatlar, 293.

55 Tosun, Bahaeddin Nakşibend, 338. 
mekandan münezzeh bir şekilde tasavvur edip bıkıp usanmadan bu hâle devâm etmelidir. İşte bu hâle vâsıl olan bir sâlik, görülen her yerde ve her şeyde Allâh Teâlâ'yı müşâhede etmeye başlayacaktır. ${ }^{56}$

Tâcüddîn b. Zekeriyyâ'ya göre bu tâbîr, mürîdin, kendisini devamlı sûrette zevk tarîki üzerine Allâh Teâlâ'nın huzûrunda olduğunu tasavvur etmesini ifâde etmektedir. Nablusî’ye göre bu tasavvur, mürîdin, Allâh Teâlâ'yı tahayyül yolu ile bilmesi şeklinde değil, vicdânen ve tahkîkîkan kalbiyle Allâh Teâlâ'nın huzûrunda olduğunu tasavvur etmesi şeklinde olmalıdır. Çünkü eşyâ hakkında aklen ya da hissen huzurda bulunma ve müşâhede etme tasavvur edilebilir; ancak bu şekilde bir tasavvur, Allâh Teâlâ hakkında câiz olmaz. Nablusî'ye göre üç türlü müşâhede vardır: Birincisi, Allâh Teâlâ'nın fiillerini müşâhede etmektir. Eğer kul, huzurda bulunurken eşyâ görünür halde ise kul, Allâh Teâlâ'nın fiillerini müşâhede makâmında bulunmaktadır. İkinci müşâhede, Allâh Teâlâ'nın sıfatlarını müşâhede etmektir. Eğer kul, huzurda bulunurken, eşyâ görünmez halde; ancak görünen şey, parlayan şimşek gibi tek bir nûr şeklinde ise bu durumda kul, Allâh Teâlâ'nın sıfatlarını müşâhede makamındadır. Üçüncü müşâhede, Allâh Teâlâ'nın zâtını müşâhede etmektir. Eğer kul, huzurda olduğu halde görünen herhangi bir şey yok ise bu durumda kul, Allâh Teâlâ'nın zâtını müşâhede makâmında bulunmaktadır. ${ }^{57}$ Nablusî'ye göre kâmil bir kulun muayyen bir makâmı olmaz. O, bu üç hâlden hangisi ile karşılaşırsa karşılaşsın, sâbit bir hâl üzere kalmaz; bir halden bir hâle intikâl eder durur. ${ }^{58}$

\section{5. Esâs: Hûş der dem}

Hûş kelimesi lügatte akıl mânâsına, dem kelimesi ise nefes mânâsına gelmektedir. Buna göre hûş der dem tâbîri, her nefesin akıllıca alınıp verilmesi, alınıp verilen her nefesin gafletten uzak tutulması manalarını ifâde etmektedir. Nefesin bu şekilde gafletten korunması, kalbin her nefes Allâh Teâlâ'nın huzûrunda olduğu idrâkine ulaşmasına

56 Bahâ̂, Büyük İslâm Velîsi Muhammed Bahaeddin Şah Nakşibendî, 119.

57 Buradaki müşâhede, gözle görme olarak anlaşılmamalıdır. Çünkü Nablûsî, müşâhede mahallinin kalp; ru'yet/görme mahallinin ise göz olduğunu söyler. Ona göre müminler, dünyâda iken kalpleri ile Allâh Teâlâ'yı müşâhede edebilirler; ancak gözleri ile O'nu göremezler. Allâh Teâlâ'yı görmek, sâdece âhirette mümkün olacaktır. (Bk. Nablûsî, Miftâhu'l-maiyye, 82.)

58 Nablûsî, Miftâhu'l-maiyye, 107. 
312 I M. ÖZÇELIK / Abdülğanî b. İsmâil en-Nablusî (ö. 1143/1731) ve Miftâhu'l-Ma'tyye Adlı Eseri Çerçevesinde Nakşibendî Tarikatının On Bir Esâsı

vesîle olur. Her nefeste, Allâh Teâlâ'nın huzûrunda olunduğu bilincine erişmek, kalbin, ibâdetler ile diriltilmesi ve mânevî hayat ile muttasıf olarak Allâh Teâlâ'ya ulaştırılması gâyesine mâtuftur. "Çünkü huzûr-1 ilâhîde olunduğu bilinciyle alınıp verilen her nefes, diridir ve Allâh Teâlâ'ya ulaştırılmıştır; gaflet ile alınan her nefes ise ölüdür ve Allâh Teâlâ'ya ulaşmaktan kesilmiştir." 59

Her nefesin Allâh Teâlâ'nın huzûrunda olunduğu bilinciyle alınıp verilmesini öğütleyen hûş der dem kavramının ${ }^{60}$ muktezâsınca hareket eden bir sâlik, nefes alıp verirken telaffuz ettiği her "he" sesi ile Allâh Teâlâ'nın zâtını hatırlamalı; verdiği her nefesin, bir hazîne olduğunu ve ömürden bir parça alıp gittiğini düşünmelidir. ${ }^{61}$ Bu bilince sâhip olan sâlik, nefeslerine sâhip olur; onları gafletten ve zâyi olmaktan korur. Nefese sâhip olmanın ehemmiyetine binâen bazıları, nefse sâhip olmanın yolunun, nefese sâhip olmaktan geçtiğine kâni olmuşlardır. ${ }^{62}$

Nablusî'ye göre bu ifâde ile kastedilen mânâ, mürîdin, kendisini huzûr-1 ilâhîde hissettiği anda ağzından çıkan her nefesi gafletten uzak bir şekilde vermesi gerektiğini ifâde etmektedir. Burada ağza giren nefesten değil de ağızdan çıkan nefesten bahsedilmektedir. Nablusî'ye göre bunun sebebi, ağza giren nefesin mürîdin kendi kontrolü dâhilinde olmaması sebebiyledir. Ancak ağızdan çıkan nefes böyle değildir. Çünkü ağızdan çıkan her nefes, sâhibini, gaflet hâlinde iken mi yoksa huzur-1 kalp hâlinde iken mi terk ettiğine dâir sorguya çekilecektir. Eğer nefes, sâhibi aleyhine şahitlik yapacak olursa o kul, Allâh Teâlâ'ya karşı gâfil olan kimselerden yazılacak; eğer nefes, sâhibinin lehine şahitlik yapacak olursa o kul, Allâh'in huzûrunda olanlardan yazılacaktır. ${ }^{63}$

Bu hassâsiyete işâreten Hâce Bahâüddîn Nakşibend, Nakşibendî yolunun nefes üzerine binâ edildiğini söylemiş; bu yüzden gaflet içinde alınıp verilmemesi için iki nefesin arasını her dâim muhâfaza etmeye çalışmak gerektiğini söylemiştir. ${ }^{64}$

59 Hânî, el-Kevâkibü'd-dürriyye, 359-360; Hânî, el-Behcetü's-seniyye, 91; Dernîka, etTarîkatü'n-Nakşibendiyye ve a'lâmühâ, 25; Nablûsî, Miftâhu'l-maiyye, 110.

60 Yılmaz, Anahatlarıla Tasavouf ve Tarîkatlar, 291.

61 Tosun, Bahaeddin Nakşibend, 335.

62 Bahaî, Büyük İslâm Velîsi Muhammed Bahaeddin Şah Nakşibendî, 117.

63 Nablûsî, Miftâhu'l-maiyye, 110.

64 Nablûsî, Miftâhu'l-maiyye, 110; Hânî, el-Kevâkibü'd-dürriyye, 360; Dernîka, etTarîkatü'n-Nakşibendiyye ve a'lâmühâ, 25; Nablûsî, Miftâhu'l-maiyye, 110. 


\section{6. Esâs: Sefer der vatan}

Sefer kelimesi sözlükte, "bir şahsın, bir beldeden başka bir beldeye gitmesi" demektir. Vatan kelimesi ise insanın kendisinde iskân ettiği ev veya belde mânâsına gelmektedir. Buna göre sefer der vatan tabiri, lügatte, "vatanda sefer yapmak" mânâsında kullanılmaktadır. Istılâhta ise sefer der vatan, mürîdin, halk âleminden Hak Teâlâ tarafına sefer yapması, yani halktan uzaklaşıp Hak Teâlâ'ya yönelmesi demektir. Bu yönelme, tıpkı Hz. İbrâhîm'in (a.s.) "Ben Rabbime gidiyorum."(Sâffât, 37/99) diyerek mensubu bulunduğu putperest halkı terk edip Allâh Teâlâ'ya yönelmesine benzemektedir. İki türlü sefer vardır: Birincisi, mürîdin mürşidinin arkasından yürüyerek bir memleketten bir başka memlekete gitmesi şeklinde gerçekleşen zâhirî sefer, diğeri ise mürîdin nefsini, hevâsını ve şehevî arzularını terk etmesi şeklinde gerçekleşen mânevî seferdir. Bu da mürîdin sâhip olduğu çirkin sıfatları terk edip güzel sıfatlarla donanmasını ifâde eder. ${ }^{65}$

Sefer der vatan tâbîri mâsivâyı terk ederek Allâh Teâlâ'ya yönelmek, kötü sıfatları terk edip ahlâkı güzelleştirmeye çalışmak, dünyâ âleminden melekût âlemine, melekût âleminden ceberût âlemine, ceberût âleminden lâhût âlemine çıkmak, ilm-i yakîn mertebesinden ayn-i yakîn mertebesine, ayn-i yakîn mertebesinden hakk-1 yakîn mertebesine erişmek gibi mânâları ihtivâ etmektedir. Nakşibendiyye yolunda sâliklerin, zâhirî mânâda yapmış oldukları seferden maksatları mânevî sefere hazırlık olmalıdır. Aksi takdirde yapılan zâhirî seferlerin hiçbir faydası olmayacaktır. ${ }^{66}$

Tâcüddîn b. Zekeriyyấya göre sefer der vatan tâbiri, mürîdin bütün varlığıyla Allâh Teâlâ'ya yönelebilmesi için kendisini halktan soyutlaması gerektiğini ifâde etmektedir ki bu da mürîdin, beşeriyet tabîatında bulunan kınanmış sıfatları terk edip övülmüş sıfatlara sefer etmesi gerektiğini ifâde etmektedir. ${ }^{67}$

Nablusî’ye göre bu sefer ile kastedilen, kulun nefsindeki tamahkârlık, hırs, cimrilik, kıskançlık, hîle ve zulüm/azgınlık gibi

65 Hânî, el-Behcetü's-seniyye, 92-93; Hânî, el-Kevâkibü'd-dürriyye, 361; Dernîka, etTarîkatü'n-Nakşibendiyye ve a'lâmühâ, 25.

66 Bahâ̂, Büyük İslâm Velîsi Muhammed Bahaeddin Şah Nakşibendî, 121; Tosun, Bahaeddin Nakşibend, 336; Türer, Ana Hatlarıla Tasavouf Tarihi, 180; Yılmaz, Anahatlartyla Tasavouf ve Tarîkatlar, 292.

67 Nablûsî, Miftâhu'l-maiyye, 111. 
314 | M. ÖZÇELIK / Abdülğanî b. İsmâil en-Nablusî (ö. 1143/1731) ve Miftâhu'l-Ma'tyye Adlı Eseri Çerçevesinde Nakşibendî Tarikatının On Bir Esâsı

beşeriyetten kaynaklanan çirkin sıfatları terk edip îsâr, müsâmaha, cömertlik, affetme, bağışlama, iç temizliği, adâlet, tevekkül, zühd, verâ ve takvâ gibi güzel ahlaklarla donanmak sûretiyle Allâh Teâlâ'ya yönelmesidir. Kulun, kınanmış sıfatlardan övülmüş sıfatlara intikal ederek yapmış olduğu sefer sâyesinde kalp, "Şüphesiz ki, bunda kalbi olan veya hazır bulunup kulak veren kimseler için bir öğüt vardır." (Kâf, 50/37) âyet-i kerîmesinde işâret edilen kalp seviyesine çıkmış olur. ${ }^{68}$

Nefsi terk ederek Allâh Teâlâ'ya doğru yapılan sefer ile ilgili bazı şeyhler, bir şahsın, bir yerden başka bir yere taşınması durumunda, terk edilmediği müddetçe habîs/kötü sıfatların da o kişi ile beraber taşınacağını söylemişlerdir. Bazıları ise bu hâli, "şahâdet âleminde gaybı görmek" olarak nitelendirmişlerdir. ${ }^{69}$

Nablusî'ye göre bir kişi, Allâh Teâlâ'yı bilme mertebesinden başka bir mertebeye geçtiği zaman tabîatının aslından kaynaklanan kötü sıfatlar, o kişiyi terk etmez. Zaten bu sıfatların tamâmen kişiden ayrılması imkânsızdır. Çünkü bu sıfatların insandan tamâmen ayrılması, beşeriyetin ortadan kalkması anlamında gelir ki bu da imkânsız bir şeydir. O halde bu sıfatların insandan ayrılması demek, bu sıfatların, kötü halden iyi hâle değişmesi demektir. Şöyle ki kul, önce dünyaya karşı tamahkâr iken Allâh Teâlâ'ya yöneldiği zaman onun tamahı, tâatlara ve Allâh Teâlâ'ya yakınlığa sebep olan amellere karşı olacak; kul, daha önce cismânî lezzetlere karşı hırslı iken nefsinden sefer ettikten sonra rûhânî lezzetlere karşı hırslanmaya başlayacaktır. Hâkezâ kul, daha önce dünyalık malları verme konusunda cimrilik yaparken daha sonra dinini başkasına verme konusunda cimri olmaya başlayacak; önce müminlere karşı kin beslerken daha sonra harp ehlinden kâfirlere karşı kin beslemeye başlayacak; önce dünyâ malına ve makâmına karşı haset ederken daha sonra dîn ve takvâya gipta etmeye başlayacak; önce müminler arasında hîle ve zulüm yaparken daha sonra Allâh yolunda kâfirlere karşı hîle ve tuzak kurmaya başlayacaktır. Nablusî’ye göre kötü sıfatların iyi sıfatlara dönüşmesi bu şekilde gerçekleşmektedir. Bu dönüşüm, kulun kurtuluşa erenler zümresine dâhil olmasına vesîle olacaktır. Yukarıda da ifâde edildiği üzere Nablusî, insânın beşeriyetinden kaynaklanan kötü sıfatları tamâmen ortadan kaldırmakla değil; o sıfatları iyi sıfatlara tebdîl etmekle mükellef olduğu

68 Nablûsî, Miftâhu'l-maiyye, 111.

69 Nablûsî, Miftâhu'l-maiyye, 111. 
M. ÖZÇELIK / The Eleven Principles of Naqshibandiyya Tariqa in the Framework of Abdulgani b. Ismail an-Nablusi (d. 1143/1731) and Miftâhu'l-Ma'ryye I 315

kanâatindedir. $\mathrm{O}$, bu düşüncesine mesnet olarak “...Ve her kim, nefsinin cimriliğinden sakınırsa, işte felâha ermiş olanlar onlardır" (Haşr, 59/9) âyet-i kerîmesini gösterir. Ona göre bu âyet-i kerîmede "nefsinin cimriliğini terk ederse" denmemiş; "nefsinin cimriliğinden sakınırsa" denmiştir. Bunun sebebi, nefisteki cimrilik sıfatının sürekli devâm etmesidir. Bu yüzden kişinin cimrilik sıfatından sakınması mümkün; ancak, onun bu sifattan tamâmen soyutlanması imkânsız bir durumdur. ${ }^{70}$

Bazı meşâyıh, "Sefer der vatan" tâbirini, şahâdet âleminde iken gayb âlemini görmek mânâsında kullanmışlardır. Nablusî, "gayb" ile iki mânânın kastedilmiş olabileceği görüşündedir. Birinci mânâya göre "gayb" ile kastedilen, Allâh Teâlâ'dır. Nitekim bazı müfessirler, "Onlar gayba inanırlar..." (Bakara, 2/3) âyet-i kerîmesindeki "gayb" kelimesini, "Allâh Teâlâ" olarak tefsîr etmişlerdir. İkinci mânâya göre "gayb" ile kastedilen, "gayb âlemi", yani "âhiret âlemi"dir." Gayb âleminin şehâdet âleminde müşâhede edilmesi, ancak şehâdet âleminde, akılla idrâk edilip duyu organları ile hissedilen bütün eşyâda, Allâh Teâlâ'yı müşâhede etmek sûretiyle olur. Bu düşünceden hareketle Nablusî, kulun, akılla ve his yolu ile varlığına şâhit olduğu her şeyde, ilk önce Allâh Teâlâ'yı müşâhede etmesi, ikinci olarak peygamberlerin bildirmiş olduğu âhiret ile alâkalı husûsları müşâhede etmesi gerektiğini söyler.71 İşte bu şekilde bir müşâhede netîcesinde, dünyâ, eksik akıllı kullar için, âhiretin zuhûr mahalli olur. Kullar, ölüm ve berzah/kabir ahvâli hakkında kâmil mânâda bir idrâke ulaştıklarında ise "dünyâ" olarak

70 Nablûsî, Miftâhu'l-maiyye, 112.

71 Nablûsî'ye göre peygamberlere hakîkî mânâda tâbi olmak, Allâh Teâlâ'ya ihlâslı bir şekilde kulluk yapan, rab olarak O'ndan tam mânâsıyla râzı olan kimseler için söz konusudur. Bu şekildeki kullar, zâhiren ve bâtınen nefsinin sâiki ile bir tek harekette bulunmazlar. Onların varlı̆̆ı, her türlü harekât ve sekenâtı Allâh Teâlâ iledir. Öyle ki, onlar bir defa gaflet ile göz kırpmış olsalar, bu hâli, büyük bir günâh ve habîs bir şirk sayarlar ve bu yüzden hemen tövbe ederler. Onlar, böyle bir hassasiyetle rablerinin kulluğuna mukayyed oldukları ve iç âlemlerini ıslâh ettikleri için rableri de onlara rubûbiyyeti ile teveccüh edip onların zâhirlerini islâh eder. Onlar bu minvâl üzerine kulluğa devâm ettikleri müddetçe Allâh Teâlâ onlara, sünnet-i nebîye ve râzî olduğu yola muvâfık sözler ve ameller nasip eder. Bu durumda, onların her türlü fiili, sözü ve düşüncesi Allâh Teâlâ'nın kontrolü altında olmuş olur. Nablûsî’ye göre kulun peygambere hakîkî mânâda tebeiyyet makâmına nâil olması ancak bu şekilde gerçekleşir. (Bk. Nablûsî, Miftâhu'l-maiyye, 74.) 
316 | M. ÖZÇELIK / Abdülğanî b. İsmâil en-Nablusî (ö. 1143/1731) ve Miftâhu'l-Ma'tyye Adlı Eseri Çerçevesinde Nakşibendî Tarikatının On Bir Esâsı

isimlendirilen eşyânın hakîkatlerini idrâk etmeye başlayacaklardır. Şehâdet âleminde gayb âlemini görmek ile kastedilen mânâ, işte bu idrakten ibârettir. ${ }^{72}$

\section{7. Esâs: Nazar ber-kadem}

Lügatte ayağa bakmak mânâsına gelen nazar ber kadem tabiri, ıstılahta, mürîdin, gözlerini harâma bakmaktan koruması için yürürken ayağına bakmasını ifâde etmektedir. Mürîdin şuursuz bir şekilde etrafa bakınması, kalpte bir takım perdenin meydâna gelmesine sebep olmaktadır. "Çünkü kalpteki perdelerin ekserisi, bakma yoluyla kalbe resmedilmiş olan sûretlerden ibârettir. Mürîdin ayaklarına bakarak yürümesinin daha başka sebepleri de vardır: Bunlardan birisi, mürîdin, gördüğü şeylerle meşgûl olarak zikirden uzaklaşmasının önüne geçmektir. Çünkü yolun başındaki bir mürîd, gelişigüzel her şeye baktığı zaman, kalben o şeylerle meşgûl olacak ve bu meşgûliyet neticesinde, kalpte farklı duygu ve düşünceler meydâna gelecektir. Ayaklara bakarak yürümenin bir başka gerekçesi, mürîdin sûfî olmayanların yüzlerine bakmasının önüne geçmektir. "Çünkü başkalarının yüzüne bakmak, sûfiyye katında mahzurlu şeylerden sayılmıştır. Saf/temiz kalpler, cilâlı aynalar gibidir. Katılaşmış kalplerde bulunan kötü ahlâk ve bozuk düşünceler, sâdece o kalbin sahiplerinin yüzüne bakmakla bile temiz olan kalplere aynen yansır." Bu şekilde yürümenin bir başka gerekçesi ise mürîdin güzel yüzlere bakarak fitneye düşmesinin önüne geçmektir. "Çünkü bakış, şeytânın oklarından bir oktur. Bu ok, kime isâbet ederse, o kişi, Allâh'ın yolunda fitneye düşer."73

Tâcüddîn b. Zekeriyyâ, nazar ber kadem tâbîrinin, mürîdin, şehirde ve sahrada, yürürken bakışının dağılmaması, gereksiz şeylere bakmaması ve kalbinin ilgi ve alâkasını dağılmaması için, başını öne eğerek ayaklarına bakması gerektiğini ifâde ettiğini söyler. Ona göre bu şekilde yürümekten maksat, sâlikin sülûkünü tamamlayıp mukaddes ilâhî hazrete nazar etme nîmetine nâil oluncaya kadar, sülûkün ilk başından îtibâren bakışlarını muhâfaza etmesidir. ${ }^{74}$

72 Nablûsî, Miftâhu'l-maiyye, 112.

73 Hânî, el-Behcetü's-seniyye, 92; Hânî, el-Kevâkibü'd-dürriyye, 357; Dernîka, et-Tarîkatü'nNakşibendiyye ve a'lâmühâ, 25; Bahâ̂, Büyük İslâm Velîsi Muhammed Bahaeddin Şah Nakşibendî, 120.

74 Nablûsî, Miftâhu'l-maiyye, 113. 
Nablusî’ye göre mürîdin başı önünde ayaklarına bakar vaziyette yürümesi, onun, gaflet içindeki insanların fiillerine şâhit olmaması ve kalbinin şâhit olunan fiiller ile alâkadâr olmaktan uzak kalması içindir. Çünkü mânevî uyanıklık içinde olan kimselere bakmak, mânevî uyanıklığa, gaflet içinde olan kimselere bakmak ta gaflete sebep olur. Bu şekilde yürümenin bir başka maksadı, mürîdin, mâneviyât yoluna ilk sülûk etmesinden îtibâren bütün himmetini, dünyevî ve uhrevî nîmetleri murâd etmekten uzak tutup sâdece eşi benzeri olmayan, her şeyi işiten ve gören Allâh Teâlâ'ya hasretmesini sağlamaktır. Bütün himmetini Allâh Teâlâ'ya hasreden mürîd, ne dünyâya ne de âhirete iltifât eder; ne kurtulmaktan ferahlanır; ne helâk olmaktan hüzünlenir; ne tarîkatte kendisi için husûle gelen bir takım hallere aldanır; ne de sâhip olduğu takvâ, verâ, tevekkül ve zühd gibi sıfatlara iltifât eder. Aynı düşünce sebebiyle Muh'yiddin İbnü'l-Arabî (ö. 638/1239) takvâ, verâ ve benzeri övülmüş sıfatları terk ederek sâdece Allâh Teâlâ ile meşgûl olmanın, bizâtihî bu sifatlarla meşgûl olmaktan daha üstün olduğunu söylemiştir. ${ }^{75}$

Nablusî'ye göre mürîd, tasavvuf yoluna sülûk edip âhiret yoluna girdiği andan îtibâren, Allâh Teâlâ'dan başka bir maksat taşımamalıdır. Tek maksadı Allâh Teâlâ olan bir mürîd, kendisine mârifetullâhın kapıları açılıp ta her şeyde, Allâh Teâlâ'nın eserini müşâhede etme şuûruna erişinceye kadar, zâhiren ve bâtınen, dünyevî ve uhrevî hiçbir işe meyletmemelidir. İşte bu hâle erişebilen bir mürîdin maddî ve mânevî gözünde Allâh Teâlâ'nın dışında hiçbir varlık kalmaz. Böyle bir mürîd, hangi eşyaya yönelirse yönelsin, tek maksadı kemâlini artırmaktır. Bu îtibarla Allâh Teâlâ'ya karşı gaflet içinde olan ve O'nunla kendi aralarına perde çekilmiş olan kimselere zarar veren işlerin tamâmı, böyle bir mürîd için zararsız hâle gelir. Nitekim âriflerden bazıları, nefsin hastalıklarının, nefse muhâlefet edilmesi durumunda, nefsin şifâsı hâline dönüşeceğini söylemişlerdir. ${ }^{76}$

\section{8. Esâs: Halvet der encümen}

Yalnızlık, tek başına yaşamak ve halk arasına karışmamak gibi mânâlara gelen ${ }^{77}$ halvet kavramı, Nakşibendiyye Tarîkatı'nda, zâhirde halvet ve bâtında halvet olmak üzere ikiye ayrılır. Zâhirdeki halvet,

75 Nablûsî, Miftâhu'l-maiyye, 115.

76 Nablûsî, Miftâhu'l-maiyye, 115.

77 Uludağ, "Halvet”, Tasavvuf Terimleri Sözlü̆̆̈̈, 156. 
318 I M. ÖZÇELIK / Abdülğanî b. İsmâil en-Nablusî (ö. 1143/1731) ve Miftâhu'l-Ma'tyye Adlı Eseri Çerçevesinde Nakşibendî Tarikatının On Bir Esâsı

mürîdin, melekût âleminin sırlarına müttalî olabilmek için insanlardan uzak bir halde boş bir yerde kalması demektir. Halvet der encümen tabiri ile kastedilen halvet, zâhirî halvet değildir. Çünkü halvet der encümen, "cemiyet içinde halvet" mânâsına gelmektedir. Bu tâbîr ile kastedilen şey, halk arasında bulunan bir mürîdin, kalben halktan uzak olması ve kendisini Allâh Teâlâ'nın huzûrunda hissetmesidir ki, bu da bir anlamda mürâkabe demektir. Bahâüddin Şâh-1 Nakşibend'in ifâdesine göre halvet der encümen, "kulun, zâhirde halk ile batında ise Hak Teâlâ ile olması" demektir. ${ }^{78}$ "Onlar, ne ticâretin ne de alışverişin kendilerini Allâh'ı anmaktan, namâz kılmaktan ve zekât vermekten alıkoymadığı adamlardır" (en-Nûr, 24/37) âyet-i kerîmesinin halvet der encümen prensibine işâret ettiği kabul edilmiştir. ${ }^{79}$

Halvet der encümen, dört duvar arasında halvet yapmak değil; halkın arasında iken kişinin kendisini dört duvar arasında zikrullâh ile meşgûl oluyormuş gibi hissetmesidir. Bu hâle vâsıl olmak, mânen kemâle ermiş salikler için söz konusudur. Yolun başındaki saliklere lâzım olan, insanlardan uzaklaşarak halvete çekilmek ve halvet hâlinde iken Allâh Teâlâ ile mânen ünsiyet kurmaya gayret etmektir. ${ }^{80}$

Nakşibendiyye tarikatında, insanlardan uzaklaşmak sûretiyle icrâ edilen halvet hoş karşılanmamıştır. Zîrâ Rasûlüllâh (s.a.v.) kendisine risâlet tebliğ edildikten sonra halveti terk etmiş; insanların arasına karışarak dîni tebliğ etmek ve insanları irşâd etmekle meşgûl olmuştur. Sahabe-i Kirâm için de aynı durum söz konusudur. Binâenaleyh hem Rasûlüllâh (s.a.v.) hem de sahabe-i Kirâm, halk arasında iken halvet hâlini yaşamışlardır. ${ }^{81}$ İşte bu sebepten Bahâuddin Nakşibend, halvette şöhret, şöhrette ise âfet olduğunu söyleyerek halktan uzak bir yerde halvet yapmayı tasvip etmemiş; halkın arasında iken halvet şuurunda yaşamayı tercîh etmiştir. ${ }^{82}$

Tâcüddîn b. Zekeriyyâ halvet der encümen tabirini, Bahâüdîn Şâh-1 Nakşibend'in târif ettiği gibi târif eder. Ona göre bu tâbîr, sâlikin,

78 Hânî, el-Behcetü's-seniyye, 93; Hânî, el-Kevâkibü'd-dürriyye, 363; Dernîka, et-Tarîkatü'nNakşibendiyye ve a'lâmühâ, 26.

79 Tosun, Bahaeddin Nakşibend, 336.

80 Bahâ̂, Büyük İslâm Velîsi Muhammed Bahaeddin Şah Nakşibendî, 120-121; Tosun, Bahaeddin Nakşibend, 337.

81 Bahaî, Büyük İslâm Velîsi Muhammed Bahaeddin Şah Nakşibendî, 121.

82 Türer, Ana Hatlariyla Tasavouf Tarihi, 180. 
zâhiren halk ile bâtınen Hak Teâlâ ile birlikte olmasını; yani, elin dünyevî işlerle meşgûliyette, kalbin ise Hak Teâlâ ile meşgûliyette olmasını ifâde etmektedir. Nablusî'ye göre mürîdin zâhiren halk ile birlikte olması, onun, konuşmada, yeme-içmede, oturup kalkmada, mübâh olan fiillerde, günaha sebep olmayan sözlerde ve her türlü ibadât ü tâatta, halk ile birlikte hareket etmesi, giysi ve benzeri husûslarda farklı bir hâl ve tavır sergilememesi demektir. Mürîdin, bâtınen Hak Teâlâ ile birlikte olması ise onun Allâh Teâlâ'yı müşâhadeye dalması ve zâhiren ve bâtınen Allâh Teâlâ dışındaki şeylere, yani mâsivâya meyletmemesi, Allâh Teâlâ'dan başka bir şey ile teskîn olmaması, O'ndan başka bir varlık hakkında konuşmaması ve her dâim O'nun huzûrunda olduğunun farkında olması şeklinde olur. "... Sen 'Allâh' de, sonra onları bırak; daldıkları bataklıkta oynayıp dursunlar!" (el-En'âm, 6/91) âyet-i kerîmesi, işte bu hâle işâret etmektedir. ${ }^{83}$

\section{9. Esâs: Vukûf-i Zamânî}

Bu tâbir mürîdin, üzerinden geçip giden zamana müttalî olmasını ve geçen zamandaki hâlinin keyfiyetinden haberdâr olmasını ifâde etmektedir. Geçen zamandaki hâlinin keyfiyetine vâkıf olan bir mürîd, hangi hâlinin şükretmeyi gerektirecek şekilde huzûr-u kalp ile geçtiğini, hangi hâlinin ise tövbe etmeyi gerektirecek şekilde gaflet içinde geçtiğini bilir ve ona göre davranır. ${ }^{84} \mathrm{Bu}$ anlayışa sâhip olan bir mürîd, bütün gayretini ortaya koyar ve her ân, aslî gâyesine müteveccih olur; her şeyi bilen ve her şeyden haberdâr olan Allâh Teâlâ'nın kendisini ihâta ettiğinin farkına varır; yaptığı her işin, Allâh Teâlâ tarafından müşâhede edildiğini düşünür ve Allâh Teâlâ'nın kulun her türlü harekât ve sekenâtına muttalî olduğunu fark eder. ${ }^{85}$

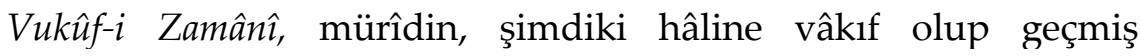
zamanını muhâsebe etmesini iktizâ eder. Bu da, mürîdin her ânını kontrol altında tutması ve her ânın gereğince amel etmesini beraberinde getirir. Böylece sâlik, hangi mertebede olursa olsun gece gündüz, her

83 Nablûsî, Miftâhu'l-maiyye, 116.

84 Bu konuda Bahâüddîn Şah-1 Nakşibend şöyle der: "Vukûf-u zamânî, senin nefsinin hallerine vâkıf olmandan ibârettir. Eğer (hâlin), şerîata uygun ve Allâh'ın râzı olduğu türden ise O'na şükret; öyle değilse O'na istiğfâr et!" (Dernîka, et-Tarîkatü'nNakşibendiyye ve a'lâmühâ, 24.)

85 Hânî, el-Behcetü's-seniyye, 91; Hânî, el-Kevâkibü'd-dürriyye, 355; Dernîka, et-Tarîkatü'nNakşibendiyye ve a'lâmühâ, 24. 
320 I M. ÖZÇELIK / Abdülğanî b. İsmâil en-Nablusî (ö. 1143/1731) ve Miftâhu'l-Ma'ryye Adlı Eseri Çerçevesinde Nakşibendî Tarikatının On Bir Esâsı

dâim nefsini muhâsebe altında tutar; vakitlerini verimli bir şekilde geçirir; varsa geçmişteki hatâlarını telâfî etmeye çalışır. ${ }^{86}$

Tâcüddîn b. Zekeriyyâ, vukûf-i zamânî tâbîrinin, mürîdin, geçen her zaman hakkında nefsini muhâsebe etmesini ifâde ettiğini söyler. Bu muhâsebe, geçen her ânın, hayır ameller ile mi yoksa şer ameller ile mi geçtiği konusunda olur. Eğer geçen zaman, hayırlı bir meşgûliyet içinde geçmiş ise şükredilmeli; şer bir amel ile meşgûliyet içinde geçmiş ise tövbe ve istiğfâr edilmelidir. Bu tövbe, her mürîdin mânevî mertebesine göre değişiklik arz eder. Çünkü ebrâr sınıfında olan kulların yapmış oldukları iyilikler, kurbiyyet makâmında olan kulların kötülükleri sayılmıştır. ${ }^{87}$

Nablusî’ye göre vukuf-i zamânî, mürîdin, geçen vakitlerinin namâz, oruç, tesbih ve benzeri ibâdetler ile mi yoksa mâsiyetler ve dînî emirlere muhâlefet etmek ile mi geçtiği konusunda gece ve gündüz, her dâim nefsini muhâsebe etmesini ifâde etmektedir. Mürîd bu muhâsebe netîcesinde, eğer vaktini hayırlı ameller ile geçirdiğini görmüş ise bu amelleri kendisine kolaylaştırdığı ve bu konuda kendisini muvaffak kıldığ1 için Allâh Teâlâ'ya şükretmeli; eğer vaktini şer ameller ile geçirdiğini görmüş ise Allâh Teâlâ'dan mağfiret dileyip tövbe etmelidir. Nablusî'ye göre bu muhâsebe, “Ey îmân edenler! Allâh'tan korkun ve herkes, yarına ne hazırladığına baksın. Allâh'tan korkun, çünkü Allâh, yaptıklarınızdan haberdardır." (el-Haşr, 59/18) âyet-i kerîmesinin muktezâsıdır. 88

Nablusî, şer amellerden dolayı yapılması gereken tövbenin, her mürîdin mânevî mertebesine göre değişiklik arz ettiğini şöyle îzâh eder:

"Bazen fiillerden herhangi biri, bir mertebede günâh iken, ondan daha aşağ 1 mertebede tâat; orta mertebede ise mübâh olur." Nablusî, bu düşüncesini destekler mâhiyette, Zünnûn-i Misrî̀nin (ö. 245/859) "Avâmın tövbesi günahlardan, havâssın tövbesi gaflettendir." sözünü nakleder. Yine aynı düşüncenin bir yansıması olarak Hasan en-Nûrî (ö. 295/908), Allâh Teâlâ dışındaki her şeyden uzaklaşmanın gerçek tövbe olduğunu söylemiştir. Muhammed et-Temîmî ise üç türlü tövbeden

\footnotetext{
86 Bahâ̂, Büyük İslâm Velîsi Muhammed Bahaeddin Şah Nakşibendî, 121.

87 Nablûsî, Miftâhu'l-maiyye, 119.

88 Nablûsî, Miftâhu'l-maiyye, 119.
} 
bahsetmiştir. Birincisi zellelerden, ikincisi gafletlerden, üçüncüsü ise iyiliklerden dolayı yapılan tövbedir. ${ }^{89}$

\section{10. Esâs: Vukûf-i adedî}

$V u k \hat{u} f-i$ adedî, zâkirin, kalp ile icrâ ettiği zikr-i hafî (gizli zikir) esnasında zikir adedinin şuûrunda olmasıdır. Esâsen zikirde mutlak olarak bir adet şart değildir, ancak vâki olacak havâtıra karşı kalbi korumak için mürîdin, kendisine târif edilen muayyen adede riâyet etmesi büyük önem arz etmektedir. Bu yüzden Nakşibendiyye Tarîkatı'nın büyüklerinden bazıları, zikirde önemli olan hususun, çok zikir yapmak değil mezkûr olan Allâh Teâlâ'nın, huzûr-u kalp ile zikredilmesi olduğuna kâil olmuşlardır. Bu konuda Bahâüddin Şah-1 Nakşibend, "Vukûf-i adedî, ilm-i ledünnînin derecelerinden birinci derecedir." demiştir. ${ }^{90}$

Tâcüddîn b. Zekeriyyâ, vukûf-i adedî tabirini, "parçalanmış havâtırı/düşünceleri bir araya toplamak maksadıyla zikr-i kalbîde muayyen bir adede riâyet etmek" olarak târif eder. Nablusî’ye göre zikir için muayyen bir adedin tâyin edilmesi, nefsi, bir adede alıştırmak ve parçalanmış haldeki düşünceleri tek bir düşüncede toplanmak maksadına mebnîdir. Mürîd sürekli muayyen bir adet üzerine zikir yaptığ 1 takdirde mürîdin nefsi, bir müddet sonra bu adede alışacak ve tereddüt etmeksizin bu adet kadar zikre boyun eğecektir. Namazdan sonraki tesbihâtın belli bir adet ile tahsîs edilmesi de aynı maksada mebnîdir. Bu îtibarla mürîd, kendisine târif edilen zikrin adedine riâyet etmelidir. ${ }^{91}$

\section{11. Esâs: Vukûf-i kalbî}

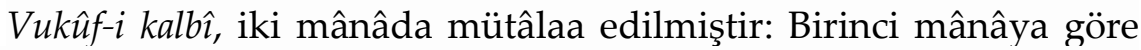
vukûf-i kalbî, zikreden kişinin kalbinin, zikir esnâsında Allâh Teâlâ'ya vâkıf olması, mürâkabe ve müşâhedesinden uzak olmadığını hissederek O'na teveccüh etmesi demektir. İkinci mânâya göre ise vukûf-i kalbî,

89 Nablûsî, Miftâhu'l-maiyye, 119.

90 Hânî, el-Behcetü's-seniyye, 91; Hânî, el-Kevâkibü'd-dürriyye, 356; Dernîka, et-Tarîkatü'nNakşibendiyye ve a'lâmühâ, 24; Bahaî, Büyük İslâm Velîsi Muhammed Bahaeddin Şah Nakşibendî, 116; Yılmaz, Anahatlarıla Tasavvuf ve Tarîkatlar, 290.

91 Nablûsî, Miftâhu'l-maiyye, 121. 
322 I M. ÖZÇELIK / Abdülğanî b. İsmâil en-Nablusî (ö. 1143/1731) ve Miftâhu'l-Ma'tyye Adlı Eseri Çerçevesinde Nakşibendî Tarikatının On Bir Esâsı

zikreden kişinin, zikir esnâsında kalbine vâkıf olması, onu kontrol altında tutması demektir. ${ }^{92}$

Vukûf-i kalbi, bir anlamda kalbin, Allâh Teâlâ'dan haberdâr olması demektir. Bu prensibe göre hareket eden sâlikin kalbi, Allâh Teâlâ'dan başka hiçbir şeyi düşünmez olur. İşte bu durumda zikr-i ilâhî, tam mânâda şuurlu bir şekilde icrâ edilmiş olur. ${ }^{93}$ Vukûf-i kalbî'den maksat, çam kozalağ1 şeklideki zâhirî kalbe benzeyen mânevî kalbe teveccüh edip aynı şuur ile kalbin hakîkî veçhesine nazar etmektir. Bu bakış netîcesinde sâlikin kalbinde bir gaybet hâli veya cezbe meydana gelir. Sâlik, sürekli olarak vukûf-i kalbî bilinci ile hareket etmesi durumunda bir müddet sonra "vuslat-1 ilellâh"a mazhar olma ve maksadına nâil olma imkânına kavuşur. Bu yüzden Nakşibendiyye yolunda vukûf-i kalbî, "vuslat ilellâh" in aslı olarak görülmüştür. ${ }^{94}$

Tâcüddîn b. Zekeriyyâ'ya göre vukûf-i kalbî, kalbin, Hak Teâlâ'nın dışında herhangi bir maksadı olmayacak şekilde O'nun karşısında uyanık halde ve huzûr-u kalp ile durması demektir. Abdülgânî enNablusî'ye göre Allâh Teâlâ'nın karşısında uyanık olmak, bütün işlerde gafleti ve unutkanlığı nefy etmek/ortadan kaldırmak demektir. O'nun karşısında huzûr-u kalp ile durmak ise Allâh Teâlâ dışında hiçbir şeye kalben iltifât etmemek demektir. Bu hâlin tahakkuk etmesi, mürîdin şâhit olduğu her şeyde, Allâh Teâlâ'yı müşâhede etmesi ile mümkündür. "Çünkü her şey, Allâh Teâlâ'nın fiillerinden bir fiildir." Buna göre kul, herhangi bir şeyi müşâhede ettiği zaman o şeyde, Allâh Teâlâ'yı müşâhede etmeli; yani o şeyin, Allâh Teâlâ'nın yaratması ile meydâna gelen bir varlık olduğunu idrâk etmelidir. Ancak burada dikkat edilmesi gereken bir husûs daha vardır: Şöyle ki kul, Allâh Teâlâ karşısında uyanık halde ve huzûr-u kalp ile dururken sâdece Allâh Teâlâ'yı murâd etmeli; O'nun dışında, sevap kazanmak, Allâh'ın azâbından kurtulmak, O'nun katında yüksek mertebelere nâil olmak gibi maksatlar taşımamalıdır. Bu da kulun ortaya koyduğu her türlü fiilin, nefsi için değil; Allâh Teâlâ'nın rızâsı için olduğunun bir ifâdesidir. ${ }^{95}$

92 Hânî, el-Behcetü's-seniyye, 91; Hânî, el-Kevâkibü'd-dürriyye, 356; Dernîka, et-Tarîkatü'nNakşibendiyye ve a'lâmühâ, 24; Yılmaz, Anahatlarıyla Tasavvuf ve Tarîkatlar, 291.

93 Türer, Ana Hatlarryla Tasavvuf Tarihi, 182.

94 Bahaî, Büyük İslâm Velîsi Muhammed Bahaeddin Şah Nakşibendî, 119.

95 Nablûsî, Miftâhu'l-maiyye, 121. 
M. ÖZÇELIK / The Eleven Principles of Naqshibandiyya Tariqa in the Framework of Abdulgani b. Ismail an-Nablusi (d. 1143/1731) and Miftâhu'l-Ma'ryye I 323

Nakşibendî Tarîkatı'ndan bazıları, "vukûf-i kalbî" tâbirinin, zikreden mürîdin, zikir esnâsında, göğsün solunda, meme hizâsında bulunan çam kozalağı şeklindeki zâhirî kalbe teveccüh etmek sûretiyle kalbine vâkıf olmasını ifâde ettiğini söylemişlerdir. Kalbe vâkıf olmak, onu, zikirle meşgûl edip zikirden ve zikrin mefhûmundan gaflete düşmesine firsat vermemekle mümkündür. ${ }^{96}$

Nablusî’ye göre kalbe vâkıf olmak, kalbe gelen havâtırı mürâkabe etmek demektir. Bu mânâya göre mürîd, Allâh Teâlâ'yı her zikredişinde, kalbine vâki olan havâtır türünden mânâları zabd u rabt altına almalı; onların güzel ve çirkin olanlarını tefrîk etmek sûretiyle kalbine vâkıf olmalıdır. Bu mürâkabe esnâsında mürîdin, göğsün sol tarafındaki memenin hizâsında bulunan çam kozalağı şeklindeki zâhirî kalbe yönelmesi, kalbi zikir ile meşgûl edip onun zikirden ve zikrin mefhûmundan gaflete düşmesine mâni olması gerekmektedir. İşte bu minvâl üzerine kalbe vâkıf olmak, kalbin mezkûr olan Allâh Teâlâ'yı mânen müşâhede etmesine ve müşâhede konusunda kalbin iyice eğitilmesine vesîle olacaktır. ${ }^{97}$

Hâce Nakşibendî̀ye göre mürîd, sâdece muayyen bir vakitte vukûf-i kalbî ile mükellef değildir: $\mathrm{O}$, hem zikir esnâsında, hem mürâkabe esnâsında hem de diğer hallerinin tamamında vukûf-i kalbi ile hareket etmekle mükelleftir. Esâsen zikir ile kastedilen şey de vukûf-i kalbî'yi husûle getirmektir..$^{98}$ Nablusî'ye göre ise vukûf-i kalbî, kalbin varlığın hakîkatini müşâhede etmesinden ibârettir. ${ }^{99}$

\section{Sonuç}

Gerek ilâhî nitelikli gerekse beşerî nitelikli olsun, her sistemin ve inancın kendine hâs bir takım usûl ve esasları vardır. Bu usûl ve esaslar, bir taraftan temsîl ettiği sistemin kökleşmesini, kurumsallaşmasını ve yaygınlaşmasını sağlarken bir taraftan da o sistemin müntesiplerinin sisteme olan bağlılıklarını sağlamada, onların kontrol edilmesinde ve aynı düşünce etrafında toplanarak dâvâ şuuru ile eğitilmelerinde önemli role sâhiptir. Aynı durum, tarikatlar için de söz konusudur. Buradan hareketle diyebiliriz ki bir tarîkat için ortaya konan usûl ve erkân, o

\footnotetext{
96 Nablûsî, Miftâhu'l-maiyye, 121.

97 Nablûsî, Miftâhu'l-maiyye, 122.

98 Nablûsî, Miftâhu'l-maiyye, 122.

99 Nablûsî, Miftâhu'l-maiyye, 123.
} 
324 | M. ÖZÇELIK / Abdülğanî b. İsmâil en-Nablusî (ö. 1143/1731) ve Miftâhu'l-Ma'tyye Adlı Eseri Çerçevesinde Nakşibendî Tarikatının On Bir Esâsı

tarîkatın müntesiplerini eğitmede, onları aynı dâvâ uğruna toplamada; hâsılı onların gönül dünyalarına hükmetmede son derece önemlidir. Çalışmamıza konu olarak seçtiğimiz Nakşibendiyye tarîkatının on bir esâsı da hem bu tarîkatın asırlar boyunca kökleşip gelişmesine, hem de farklı coğrafyalardaki tarîkat müntesiplerinin aynı usûl ve esaslar ile eğitilmelerine katkı sağlamıştır.

Derinlemesine tetkik edildiğinde görülür ki Nakşibendiyye'nin on bir temel esâsı, ya doğrudan ya da dolaylı olarak Kur'ân-1 Kerîm'e ve Sünnet-i Nebeviyye'ye dayanmaktadır. Bunun böyle olması, bu tarîkatı tesis eden mutasavvıfların Ehl-i Sünnet îtikâdına sımsıkı bağlı olmalarının tabîi bir sonucudur. Makalemize konu olarak seçtiğimiz eserin müellifi olan Abdülgani b. İsmail en-Nablusî de henüz tasavvufa sülûk etmeden önce zâhirî ilimleri tahsil etmiş ve tasavvufî düşüncesini sağlam temeller üzerine oturtmuş bir âlimdir. Bu îtibarla denilebilir ki şer'î ilimlerin hemen her sahasında kendisini geliştirmiş bir mutasavvıfın kaleminden çıkmış olan Miftahu'l-maiyye isimli eser, incelenmeye değer eserlerden biridir. Biz bu çalışmada, söz konusu eserin Nakşibendiyye Tarikatı'nın on bir esasını konu alan üçüncü bölümünü incelemeye çalıştık. Çalışmamız netîcesinde şu sonuca varmış olduk: Nakşibendiyye Tarikatı'nın on bir esası, her ne kadar bu tarikata mensup olan müritlerin mânevî gelişimlerini sağlamak maksadı ile tesis edilmiş olsalar da bu tarîkata mensup olmayanlara da hitap eder nitelikte prensiplerdir.

\section{Kaynakça}

A'zam, Cemîl. Ukûdü'l-cevher fî terâcimi men lehüm hamsûne tasnîfen femietü fe-ekser. Beyrut: el-Matba'atü'l-ehliyye, 1326/1908.

Bağdâdî, İsmâil Paşa. Hediyyetü'l-ârifinn. 2 Cilt. İstanbul: y.y., 1951.

Bahaî, Nasrullah. Büyük İslâm Velîsi Muhammed Bahaeddin Şah Nakşibendî Hayâtı, Şahsiyeti, Menkibeleri. nşr. Taşköprülü Ali Altın. İstanbul: M. Şevket Eygi Matbaas1, 1328/1966.

Alâaddin, Bekrî. Bir Çağın Öncüsü Abdülganî Nâblusî Hayâtı ve Fikirleri. çev. Veysel Uysal. İstanbul: İnsan yayınları, 1995.

Cihan, Ahmet Kamil. Abdülganî Nâblusî'nin Hayâtı ve Kelâmî Görüşleri. Kayseri: Erciyes Üniversitesi, Sosyal Bilimler Enstitüsü, Yüksek Lisans Tezi, 1988. 
M. ÖZÇELIK / The Eleven Principles of Naqshibandiyya Tariqa in the Framework of Abdulgani b. Ismail an-Nablusi (d. 1143/1731) and Miftâhu'l-Ma'ryye I 325

Dernîka, Muhammed Ahmed. et-Tarîkatü'n-Nakşibendiyye ve a'lâmühâ. Trablus: Jarrous Press, 1408/1987.

Hânî, Abdülmecîd b. Muhammed. el-Kevâkibü'd-dürriyye ale'l-hadâikı'lverdiyye fì ecillâi's-sâdâti'n-Nakşibendiyye. tsh. Muhammed Halid elHarse. Dımaşk: Dâru'l-Beyrûtî, 1996.

Hânî, Muhammed b. Abdullah. el-Behcetü's-seniyye fì âdâbi't-Tarîkati'lAliyyeti'l-Hâlidiyyeti'n-Nakşibendiyye. İstanbul: İhlas Vakfı Yayınlar1, 1381/2002.

Hasenî, Şerîf Abdulhay b. Fahruddîn. Nüzhetü'l-havâtır ve behcetü'lmesâmi've'n-nevâzır. Beyrut: Dâru İbn-i Hazm, 1. Basım, 1420/1999.

Kuşeyrî, Abdülkerîm. er-Risâletü'l-Kuşeyriyye. tsh. Hânî el-Hâc. Kâhire: el-Mektebet't-tevfîkıyye, ts.

Mekkî, Ebû Tâlib Muhammed b. Ali. Kûtü'l-kulûb fî̀ mu'âmeleti'l-mahbûb. 2 Cilt. Beyrut: Dâru'l-fikr, ts.

Mete, Ayşegül. "Nakşibendiyye-Tâciyye'nin Kurucusu: Tâceddîn b. Zekeriyyâ Hayatı, Eserleri ve Tasavvufî Yolu". Türkiyat Araştırmaları Dergisi 32 (2012): 179.

Muhıbbî, Muhammed Emin b. Fazlullah b. Muhibbillah ed-Dımaşkî. Hulâsatü'l-eser fì a'yâni'l-karni'l-hâdi aşer. 4 Cilt. Kahire: Matbaatu'lvehbiyye, 1284.

Murâdî, Ebû'l-Fazl Muhammed Halil. Silkü'd-dürer fî a'yâni'l-karni's-sânî aşer. 4 Cilt. Bağdad: Mektebetü'l-mesnâ, ts.

Nablusî, İsmail b. Abdülğanî. Miftâhu'l-ma'ryye fî düstûri't-Tarîkati'nNakşibendiyye. thk. Cevdet Muhammed Ebü'l-Yezîd el-Mehdî. Kâhire: ed-Dâru'l-cûdiyye, 1429/2008.

Nablusî, İsmail b. Abdülğanî. Miftâhü'l-maiyye fî tarîki'n-Nakşibendiyye. Konya: Konya Bölge Yazmalar Kütüphanesi, 3604/1, 1b-60a. yazmalar.gov.tr.

Nablusî, İsmail b. Abdülğanî. Tercüme-i Miftâhü'l-maiyye fi tarîkati'nNakşibendiyye. çev. Osman Bahri b. Muhammed Emin Şeyhluli. Ankara: EHT A 30939/EHT A 35408, 280 sayfa. millikutuphane.gov.tr.

Nahlî, Şihâbüddîn Ahmed b. Muhammed el-Mekkî. Büğyetü't-tâlibîn libeyâni'l-meşâyihı'l-muhakıkîni'l-mu'temedîn. Haydarabad: Matbaatü meclis-i dâirati'l-meârifi'n-nizâmiyye, 1. Basım, 1328. 
326 | M. ÖZÇELIK / Abdülğanî b. İsmâil en-Nablusî (ö. 1143/1731) ve Miftâhu'l-Ma'tyye Adlı Eseri Çerçevesinde Nakşibendî Tarikatının On Bir Esâsı

Nebhânî, eş-Şeyh Yûsuf b. İsmâil. Câmi'u Kerâmâti'l-Evliyâ. thk. İbrâhim Atve Ivaz. 2 Cilt. Porbandar: Merkez-i Ehli Sünnet Berakât-i Razâ, $1422 / 2001$.

Öngören, Reşat. "Taceddin b. Zekeriyya". Türkiye Diyanet Vakfi İslâm Ansiklopedisi. 39/342-343. Ankara: TDV Yayınları, 1996.

Öteleş, Zeliha. Abdülganî en-Nâblusî Şerhi Bağlamında İbnü'l-Fârı'ın Kasîde-i Tâiyye'sinde Seyr u Sülûk. İstanbul: Marmara Üniversitesi, Sosyal Bilimler Enstitüsü, Doktora Tezi, 2014.

Özaydın, Murat. "Şeyh Abdurrahman'a Göre Nakşibendîliğin On Bir Temel Esası". Elektronik Sosyal Bilimler Dergisi 13/50 (2014), 214.

Özel, Ahmet. "Nablusî, Abdülganî b. İsmâil”. Türkiye Diyanet Vakfı İslam Ansiklopedisi. 32/268. Ankara: TDV Yayınları, 2006.

Sâbûnî, Muhammed Ali. Safvetü't-tefâsîr. Beyrut: Dâru'l-Kalem, 1980.

Sem'ânî, Ebû Sa'd Abdülkerîm b. Muhammed b. Mansûr. el-Ensâb. thk. Abdülfettâh Muhammed el-Hulv. 8. Cilt. Beyrut: y.y., 1981.

Toprak, Mehmet Sait. “İnsan'ın Anlamı Üzerine Bir Araştırma: Abdülganî En-Nablusî". Dokuz Eylül Üniversitesi İlahiyat Fakültesi Dergisi 26 (2007), 45-82.

Tosun, Necdet. Bahaeddin Nakşibend: Hayatı, Görüşleri, Tarikatı. İstanbul: İnsan Yayınları, 1. Basım, 2002.

Tosun, Necdet. "Nakşibendiyye" (Âdâb ve Erkân). Türkiye Diyanet Vakfı İslâm Ansiklopedisi. 32/342. Ankara: TDV Yayınları, 2006.

Türer, Osman. Ana Hatlarıyla Tasavouf Tarihi. İstanbul: Seha Neşriyat, 1998.

Uludağ, Süleyman. Tasavouf Terimleri Sözlü̆̆̈̈. İstanbul: Kabalcı Yayınları. 2005.

Uysal, Muhittin. Tasavouf Kültüründe Hadis. Konya: Yediveren Yayınları, 2001.

Yılmaz, H. Kâmil. Anahatlarıyla Tasavouf ve Tarîkatlar. İstanbul: Ensar Neşriyat, 11. Basım, 2007.

Ziriklî, Hayruddîn. el-E'lâm: Kâmûsü terâcimi'l-eşhüri'r-ricâl ve'n-nisâi mine'l-arabi ve'l-müste'ribîne ve'l-müsteşrikîn. 11 Cilt. Beyrut: Dâru'lilmi'l-melâyîn, 15. Basım, 2002. 